\title{
NEW INSIGHTS ON THE ROLE OF ENVIRONMENTAL DYNAMICS SHAPING SOUTHERN MESOPOTAMIA: FROM THE PRE-UBAID TO THE EARLY ISLAMIC PERIOD
}

\author{
By Mark Altaweel, Anke Marsh, JaAfar Jotheri, Carrie Hritz, Dominik Fleitmann, \\ STEPHANie Rost, StePHen F. LinTner, MCGuire Gibson, MATTHEW BosomWORTh, \\ MATTHEW JACOBSON, EduARdo GARZANTI, MARA Limonta AND GiUditTA RADEFF
}

\begin{abstract}
Recent fieldwork and archival sedimentary materials from southern Iraq have revealed new insights into the environment that shaped southern Mesopotamia from the pre-Ubaid (early Holocene) until the early Islamic period. These data have been combined with northern Iraqi speleothem, or stalagmite, data that have revealed relevant palaeoclimate information. The new results are investigated in light of textual sources and satellite remote sensing work. It is evident that areas south of Baghdad, and to the region of Uruk, were already potentially habitable between the eleventh and early eighth millennia B.C., suggesting there were settlements in southern Iraq prior to the Ubaid. Date palms, the earliest recorded for Iraq, are evident before 10,000 B.C., and oak trees are evident south of Baghdad in the early Holocene but disappeared after the mid-sixth millennium B.C. New climate results suggest increased aridity after the end of the fourth millennium B.C. For the third millennium B.C. to first millennium A.D., a negative relationship between grain and date palm cultivation in Nippur is evident, suggesting shifting cultivation emphasising one of these crops at any given time in parts of the city. The Shatt en-Nil was also likely used as a channel for most of Nippur's historical occupation from the third millennium B.C. to the first millennium A.D. In the early to mid-first millennium A.D., around the time of the Sasanian period, a major increase in irrigation is evident in plant remains, likely reflecting large-scale irrigation expansion in the Nippur region. The first millennium B.C. to first millennium A.D. reflects a relatively dry period with periodic increased rainfall. Sedimentary results suggest the Nahrawan, prior to it becoming a well-known canal, formed an ancient branch of the Tigris, while the region just south of Baghdad, around Dalmaj, was near or part of an ancient confluence of the Tigris and Euphrates.
\end{abstract}

Keywords: southern Mesopotamia, Nippur, Uruk, environment, palaeochannels, climate, speleothems, phytoliths, sediments, date palm, oak

\section{Introduction}

New fieldwork focusing on the paleoenvironment and past channel systems was carried out during 2016-2017 in southern Iraq. This work focused on gaining a better understanding of long-term palaeochannel and environmental development during prehistoric and historic periods. Boreholes were drilled in the Dalmaj and Nahrawan regions south of Baghdad (Fig. 1) in order to obtain sedimentary samples for analyses. ${ }^{1}$ The new samples were combined with previously recovered sediments from Nippur's ancient channel (Shatt en-Nil) that ran through the city and with sediments recovered from a borehole near Uruk. Sediments were analysed for their structure, petrography, mineralogy, and microfossil remains, with phytoliths being a particular focus, and absolute dates were obtained using Accelerator Mass Spectrometry (AMS) methods where possible. New results also include palaeoclimate proxy data obtained from a speleothem (stalagmite) sample from Shalaii cave in the Kurdistan region of Iraq, dated using UraniumThorium dating. These combined data provide a long-term, environmental and hydrologic history in southern Mesopotamia that can now be juxtaposed to archaeological and historical data. Results provide insights into the plant ecology and human-environmental interactions that shaped southern Mesopotamia in different millennia.

In this article, we summarize the new results while also focusing on particular periods and instances where novel insights are gained. Up to this point, much of southern Mesopotamia's

\footnotetext{
${ }^{1}$ Borings in a third area, the Sawa Lake south of Najaf, were not productive due to extremely high salt content.
} 


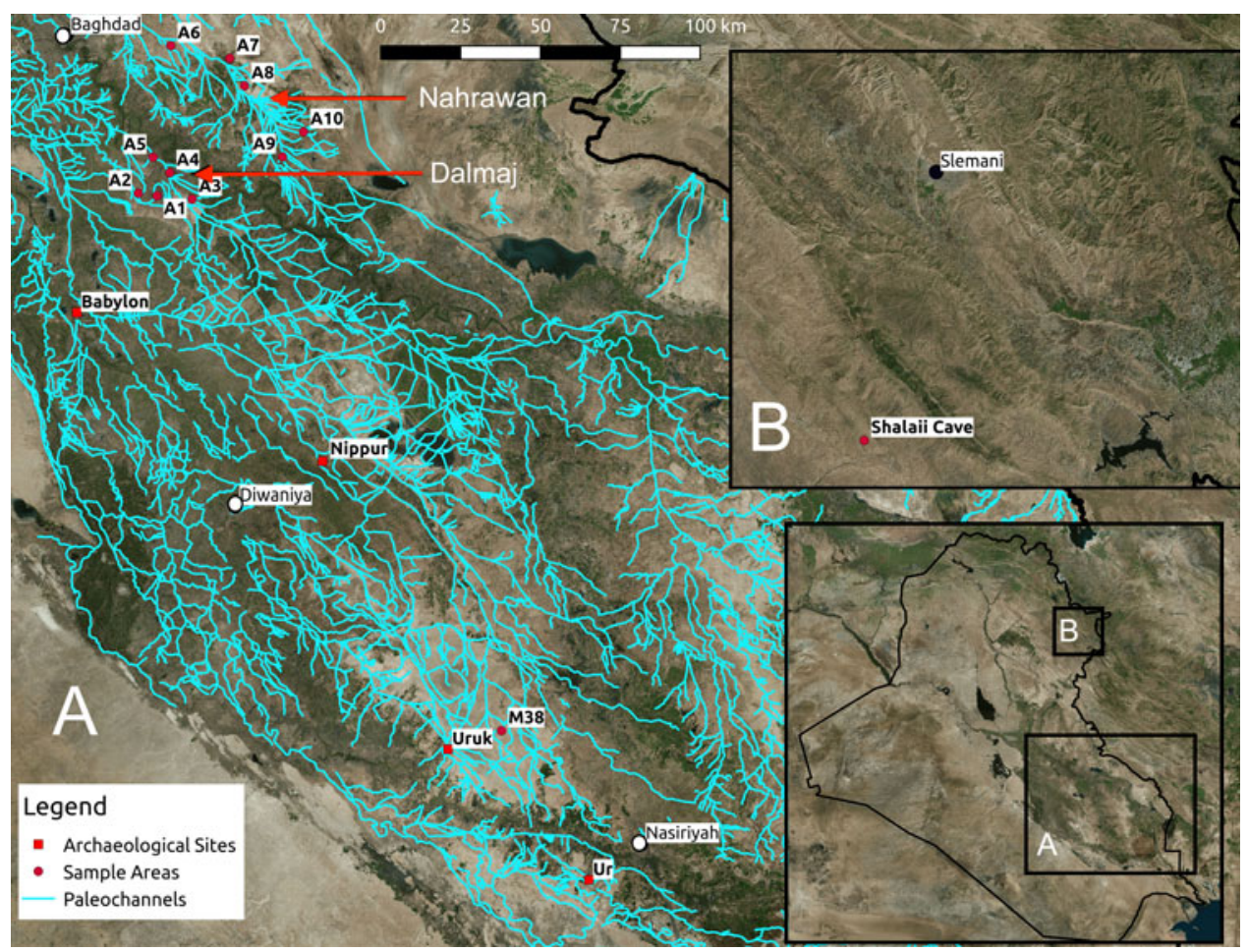

Fig. 1 Locations of fieldwork areas in southern Iraq. Inset A: numbers prefixed with A are sites of boreholes on the Naharwan and Dalmaj channels. Nippur and borehole M38 near Uruk are also indicated. Inset B: location of Shalaii cave in the Kurdish region of Iraq

environmental history has been determined through evident surface remains, such as ancient river courses or canals dated by spatial association with archaeological sites, or geomorphological techniques that assess sedimentary remains. Furthermore, there is a lack of knowledge of Iraq's ancient botanical remains, including prehistoric and historic periods. For the first time in the study of ancient southern Mesopotamia, we focus on microfossil and sedimentary data and combine terrestrial proxy climate data from cave speleothems to gain novel insight into wider environmental and landscape change.

This article begins by presenting existing research on the palaeolandscapes and environmental history of southern Mesopotamia. This includes geoarchaeological, archaeological, remote sensing, and some textual analysis. Our methods are then presented, demonstrating where our work builds from these earlier efforts, and our new results are described. Finally, a discussion on the novel insights obtained and benefits of this type of research for understanding Mesopotamian environmental history is given, in light of previous archaeological and historical data.

\section{Archaeology, Geoarchaeology and History}

Beginning in the 1950s and continuing nearly unabated until 1990, archaeologists endeavoured to document and understand the settlement and environmental history of southern Mesopotamia. Work initially focused on excavation of large mounded sites (tells) that mark the landscape and represent the accumulated material remains of long-term occupation (Adams 1981; Gibson 1972; Hritz 2010; Wright 1980). While these features reflect the importance of place in the long history of southern Mesopotamia, archaeologists also recognized the important role of landscape and environment, specifically the ancient rivers and canals, in shaping settlement history. The guiding premise in these earlier works was that durable human settlement in ancient Mesopotamia was only possible along river channels and canals, and that changes in watercourses would be accompanied by changes in settlement locations. 
The first attempts to associate tells with relict river channels, thereby providing dates of visible relict channels by association with dated tell sites and demonstrating the linkages between channels, canals, and settlement history, were made by the Diyala Basin Archaeological project begun in 1937 and led by Thorkild Jacobsen (1982) and Robert McC. Adams (1965). Adams and Jacobsen postulated that by systematically mapping all mounded sites in the region, dating them by examining visible pottery on the surface, associating them with locations mentioned in textual records, and plotting them on period maps, any linear patterns that emerged would represent the major routes of ancient water courses. In other words, spatial distributions of tells were used to infer the location of channels and canals that were no longer visible or only partially visible on the ground. Using this method, archaeologists surveyed around one third of the entire alluvial plain, plotting and postulating key hydrologic events, including avulsion, siltation, and salinisation, while associating these changes to changes in the fortunes of settlements (Adams 1981; Gibson 1972; Jacobsen 1960; Jacobsen and Adams 1958). Work by Adams (1965) in the Diyala used archaeological survey and historical data together to understand periods of environmental stress affecting settlements, where channel abandonment, including that of canals, was seen as related to settlement abandonment.

Another frequently cited environmental reason explaining the abandonment of settlements and even the collapse of major early states is salinisation induced by irrigation (Jacobsen 1982; Jacobsen and Adams 1958). The primary evidence for salinisation comes from the analysis of ancient texts. The term ki-mun ('saline ground') was used to classify the fertility of soils from 2500 B.C. onwards. Surveys of agricultural ground delineate parcels as saline ground that remained uncultivated due to salinisation (Jacobsen 1982: 8-9). Scholars have also compared texts recording crop yield and yield projections and used changing amounts to suggest cycles of progressive salinisation, including impact on the health of early states' economies (Algaze 1993: 4-5, 104-106; Civil 1987: 39-44; Gibson 1974; Maekawa 1974; Sallaberger 1999: 175-177). The most comprehensive study of ancient crop yields and projections (third millennium B.C. through first millennium A.D.) was made by Jacobsen (1982). He argued that progressive salinisation promoted the switch at the beginning of the Akkadian Period (2335-2120 B.C.) from cultivating primarily emmer wheat to farming almost exclusively more salt tolerant barley in the alluvial plain (Jacobsen 1982: 15-17; see also Helbaek 1960: 195). This conclusion has been questioned by Powell (1985), who criticized not only the translation of key elements of the textual data but also noted that the preference for barley in southern Mesopotamia might have been related to its greater productivity, better adaptability and greater tolerance to seasonal variation (see also Helbaek 1959: 370).

Building on the earlier extant approaches to understanding environmental and settlement pattern changes over time and space, a few local-scale survey and excavation projects demonstrated the importance of diverse micro-topography and environment within the alluvial plains. For example, field studies by Mahringer, Lintner and Brandt undertaken as part of the Nippur Expedition in the 1970s-80s (Gibson 1976, 1977 and 1978) focused on examination of historical and contemporary environmental processes in the central alluvial plain landscape, on both a local and regional level, and the relationship of these processes to the city, including how they might have influenced the course of the ancient Euphrates in relation to the urban (Brandt 1990). Work around Abu Salabikh also focused on channel change, as well as settlement and landscape change, demonstrating the important interplay between processes and cycles of erosion, plain scour, sedimentation, and marsh development in a seemingly homogeneous agricultural landscape (Wilkinson 1990). Collaborative geoarchaeological, archaeological, and historical analysis around Tell ed-Dēr in the 1970s focused on reconstructing and better understanding the relationship of the Euphrates and Tigris-Euphrates belt around the site (Paepe 1971; Paepe and Baeteman 1978), demonstrating the presence of layers of contemporaneous and diachronic relict river levees, identified through multiple datasets. Later efforts combined textual and archaeological sources with continued geoarchaeological work (Heyvaert et al. 2008; Cole and Gasche 1998; Morozova 2005; Verhoeven 1998). Taken together, the interdisciplinary work at Nippur, Tell edDēr and Abu Salabikh, along with the shift to closer analysis of sediments to understand channel 
change, demonstrated the value of landscape and environmental proxy records for micro-topographic analysis of natural and ecological data. The outcome of these efforts is the broad recognition that the Mesopotamian landscape is a palimpsest, where the premise that linear site alignments always demarcate canals provides only a small portion of palaeochannel and settlement history.

During the late 1990s, although foreign work had largely stopped in southern Iraq, new access to high resolution satellite imagery, in particular CORONA imagery, allowed palaeochannels to be more easily identified and encouraged archaeologists to analyse areas beyond survey boundaries. CORONA satellites were in operation from the 1950s to 1970s, giving researchers the opportunity to map palaeochannels across Mesopotamia before the large landscape altering land reclamation projects of the 1970s. Later satellite data included higher resolution imagery, including QuickBird, and relatively easy access to digital elevation models (DEM) provided by different satellite and radar systems, such as the Shuttle Radar Topography Mission (SRTM). For the first time, these datasets provided archaeologists with a broad and encompassing view of the alluvial plains, including its micro-topography, enabling base images for time-series comparisons. Work by Pournelle (2003), Hritz (2005) and al-Hamdani (2014) focused on areas previously unsurveyed by archaeologists, including the former Haur al-Hawiza and Hammar marshes, the Shatt al-Gharraf, and Tigris and Euphrates levees. Using remote datasets and applying geoarchaeological principles of landscape change (Wilkinson 2003), these studies identified possible new archaeological sites and landscape features such as irrigation works or habitable regions.

Beginning in 2010, Hritz et al. (2013) began ground truthing features detected on imagery, both validating the methodological approach and illustrating the complexity of landscape evolution in southern Mesopotamia. Collecting targeted samples from archaeological sites and relict visible canals, this work demonstrated that (1) preservation in southern Iraq is such that sections exposed in historical excavations may still yield reliable AMS dates, and (2) proxy records such as shell and sediment cores can shed light on long-standing questions about landscape, such as the evolution and extent of marsh formation and canal development in antiquity (Hritz et al. 2012: 77). Jotheri (2016) has greatly added to our knowledge about palaeochannels, including relict rivers and canals, through imagery analysis and subsequent ground truthing, including dating these features using augering, structural remains in sediments, mineralogy, and AMS dating.

On the historical side, considerable progress has been made in gathering textual sources to reconstruct ancient environments and historical geographies (Blaschke 2018; Cancik-Kirschbaum and Ziegler 2009; |Reculeau 2008, 2015, 2011; Rost 2015; Schrakamp 2015, 2017; Vanderroost 2012). This progress is largely due to the recent availability of online databases of ancient texts (e.g., Database of Neo-Sumerian Texts [BDTNS], Cuneiform Digital Library Initiative [CDLI], Ebla Digital Archives, Archives Babyloniennes [ARCHIBAB], etc.), which allow for the digital sourcing and more systematic analysis of entire text corpora. The success of integrating textual and archaeological data in the reconstruction of ancient environments has been demonstrated by Cole and Gasche (1998), and currently there are several ongoing projects adopting such a combined approach (e.g., Historische Geographie Obermesopotamiens [HIGEOMES]; CancikKirschbaum and Hess 2016; Fink 2016; Ziegler and Langlois 2016).

These studies demonstrate the value of environmental data collection and analysis. With renewed foreign access to southern Iraq and the emergence of different techniques to collect, integrate, and analyse data, a large, regional-scale sampling program is possible, to reconstruct a general picture of long-term social, environmental, and historical change in southern Mesopotamia.

\section{Methods}

Most previous work in southern Mesopotamia focused on macro-remains, visible to the naked eye. Our work, while using satellite imagery (i.e., CORONA and QuickBird imagery) to identify palaeochannels, has also focused on combing microfossil, petrographic, and heavy mineral composition. Furthermore, new proxy data on the paleoclimate from cave speleothems now allow us to contextualize some results with climate trends, including their relation to the hydrologic cycle. Table 1 summarizes the dated sediments and samples discussed below, showing sample numbers, sediment types, dates, coordinates (in UTM $38 \mathrm{~N}$ ), and materials used for absolute dating. 
TABLE 1 Summary of remains, key contents, locations (UTM 38N), and dated levels for sediments and speleothem samples. The Sample column indicates the sample number (e.g., A3) and depth (e.g., A3-4, with '4' being depth in metres), where present. Not all samples are given in detail here; the list mostly provides dated samples and samples discussed in the text. Calibration for AMS dates employs IntCal13 (Reimer et al. 2013) and was conducted by Beta Analytic.

\begin{tabular}{|c|c|c|c|c|c|c|c|}
\hline Region & Sample & $\begin{array}{l}\text { Sediment/ } \\
\text { Reference }\end{array}$ & $\begin{array}{l}\text { Without } \\
\text { dl3C } \\
\text { Correction }\end{array}$ & Calibrated Date & $X$ & $Y$ & $\begin{array}{c}\text { Dated } \\
\text { Material }\end{array}$ \\
\hline Dalmaj & A1 & & & & 470713 & 3635889 & \\
\hline Dalmaj & A1-5 & $\begin{array}{l}\text { Sandy- } \\
\text { Silty-Clay }\end{array}$ & & & 470713 & 3635889 & \\
\hline Dalmaj & A2 & & & & 465005 & 3636683 & \\
\hline Dalmaj & A2-3 & Fine Sand & & & 465005 & 3636683 & \\
\hline Dalmaj & $\mathrm{A} 3$ & & & & 481449 & 3634876 & \\
\hline Dalmaj & A3-2 & Silty-Clay & & & 481449 & 3634876 & \\
\hline Dalmaj & A3-3 & Silty-Clay & $\begin{array}{l}6770+/- \\
30 \mathrm{BP}\end{array}$ & $\begin{array}{l}\text { c. } 5743-5645 \text { BC } \\
(95 \%)\end{array}$ & 481449 & 3634876 & Gyttja \\
\hline Dalmaj & A3-4 & Sandy-Clay & $\begin{array}{l}8520+/- \\
30 \mathrm{BP}\end{array}$ & $\begin{array}{l}\text { c. } 7601-7546 \text { BC } \\
(95 \%)\end{array}$ & 481449 & 3634876 & Gyttja \\
\hline Dalmaj & A4 & & & & 474667 & 3642892 & \\
\hline Dalmaj & A4-4 & Fine Sand & & & 474667 & 3642892 & \\
\hline Dalmaj & A5 & Silty-Clay & & & 469557 & 3647641 & \\
\hline Nahrawan & A6 & & & & 475064 & 3681522 & \\
\hline Nahrawan & A7 & & & & 493050 & 3677679 & \\
\hline Nahrawan & A8 & & & & 497536 & 3669338 & \\
\hline Nahrawan & A9 & & & & 509095 & 3647704 & \\
\hline Nahrawan & A9-2 & Sandy-Clay & $\begin{array}{l}6210+/- \\
30 \mathrm{BP}\end{array}$ & $\begin{array}{l}\text { c. } 5306-5204 \mathrm{BC} \\
(75 \%) ; 5167-5076 \mathrm{cal} \\
\mathrm{BC}(20.7 \%)\end{array}$ & 509095 & 3647704 & Gyttja \\
\hline Nahrawan & A9-3 & Fine Sand & & & 509095 & 3647704 & \\
\hline Nahrawan & A9-4 & Sandy-Clay & $\begin{array}{l}10430+/- \\
30 \mathrm{BP}\end{array}$ & $\begin{array}{l}\text { c. } 10,488-10,175 \text { BC } \\
(79 \%) ; 10577-10511 \\
\text { BC }(16.2 \%)\end{array}$ & 509095 & 3647704 & Gyttja \\
\hline Nahrawan & A10 & & & & 515553 & 3655370 & \\
\hline Nahrawan & A10-4 & Fine Sand & & & 515553 & 3655370 & \\
\hline Nippur & $300-311$ & $\begin{array}{l}\text { Mostly } \\
\text { silty-clay, } \\
\text { some sand }\end{array}$ & & & 5034796 & 3780305 & \\
\hline Nippur & $\begin{array}{l}310 \\
(0.5 \mathrm{~m})\end{array}$ & Silty-Clay & $\begin{array}{l}1210+/- \\
30 \mathrm{BP}\end{array}$ & $\begin{array}{l}\text { c. } 766-898(89 \%) ; 924- \\
945(3.5 \%) ; 722-740 \\
(2.9 \%)\end{array}$ & 5034796 & 3780305 & Charcoal \\
\hline Nippur & $\begin{array}{l}307 \\
(2.0 \mathrm{~m})\end{array}$ & Silty-Clay & $\begin{array}{l}1270+/- \\
30 \mathrm{BP}\end{array}$ & $\begin{array}{l}\text { c. } 662-778(92 \%) ; 842- \\
859(1.6 \%) ; 792-804 \\
(1.3 \%) ; 818-821 \\
(0.2 \%)\end{array}$ & 5034796 & 3780305 & Charcoal \\
\hline Nippur & $\begin{array}{l}304 \\
(3.5 \mathrm{~m})\end{array}$ & Silty-Clay & $\begin{array}{l}1580+/- \\
30 \mathrm{BP}\end{array}$ & c. $85-235(95 \%)$ & 5034796 & 3780305 & Shell \\
\hline Nippur & $\begin{array}{l}301 \\
(5.0 \mathrm{~m})\end{array}$ & $\begin{array}{l}\text { Silty-Clay- } \\
\text { Fine Sand }\end{array}$ & $\begin{array}{l}3720+/- \\
30 \mathrm{BP}\end{array}$ & $\begin{array}{l}\text { c. } 2578-2457 \mathrm{BC} \\
(95 \%)\end{array}$ & 5034796 & 3780305 & Shell \\
\hline Nippur & $\begin{array}{l}300 \\
(5.5 \mathrm{~m})\end{array}$ & $\begin{array}{l}\text { Silty-Clay- } \\
\text { Fine Sand }\end{array}$ & $\begin{array}{l}3730+/- \\
30 \mathrm{BP}\end{array}$ & $\begin{array}{l}\text { c. } 2577-2468 \text { BC } \\
(95 \%)\end{array}$ & 5034796 & 3780305 & Shell \\
\hline Uruk Region & M38 & $\begin{array}{l}\text { see Jotheri } \\
\text { et al. } 2017\end{array}$ & & & 577390 & 3472026 & \\
\hline Uruk Region & M38-5 & $\begin{array}{l}\text { see Jotheri } \\
\text { et al. } 2017\end{array}$ & & $\begin{array}{l}\text { c. } 3980-3940 \mathrm{BC} \\
(95 \%)\end{array}$ & 577390 & 3472026 & Shell \\
\hline Uruk Region & M38-7 & $\begin{array}{l}\text { see Jotheri } \\
\text { et al. } 2017\end{array}$ & & $\begin{array}{l}\text { c. } 4900-4860 \mathrm{BC} \\
(95 \%)\end{array}$ & 577390 & 3472026 & Shell \\
\hline Uruk Region & $\begin{array}{l}\text { M38- } \\
12.5\end{array}$ & $\begin{array}{l}\text { see Jotheri } \\
\text { et al. } 2017\end{array}$ & & $\begin{array}{l}\text { c. } 7750-7600 \mathrm{BC} \\
(95 \%)\end{array}$ & 577390 & 3472026 & Shell \\
\hline Shalaii Cave & SHC-1 & $\begin{array}{l}\text { see Marsh } \\
\text { et al. } 2018\end{array}$ & & $\begin{array}{l}\text { c. } 938( \pm 42)-1456 \\
( \pm 29)\end{array}$ & 526935 & 3889333 & Stalagmite \\
\hline Shalaii Cave & SHC-2 & $\begin{array}{l}\text { see Marsh } \\
\text { et al. } 2018\end{array}$ & & $\begin{array}{l}\text { c. } 6075( \pm 38)-5027 \\
( \pm 219) \text { BC }\end{array}$ & 526935 & 3889333 & Stalagmite \\
\hline Shalaii Cave & SHC-3 & & & $\sim 8500$ BC-present & 526935 & 3889333 & Stalagmite \\
\hline
\end{tabular}




\section{Geoarchaeology and Satellite Imagery}

The primary goal of fieldwork was identifying and sampling from palaeochannels across southern Mesopotamia, as these channels act as environmental traps that allow dating and also contain microfossils that reflect the surrounding paleoenvironment. Palaeochannels were identified and selected using CORONA and QuickBird images, where channels can be seen as sinuous linear features that cast shadows on imagery. Identified paleochannels were then selected for fieldwork based on their visibility in the floodplain as well as possible historical relevance. Figure 1 shows the palaeochannels identified and the areas where fieldwork was conducted. This includes areas that were sampled using hand augering in the Dalmaj (A1-5) and Nahrawan (A6-10) regions. Figure 2 shows the sedimentary results from fieldwork. Boreholes A1-A10 were taken to a depth of six meters, with the exception of A2 and A3 that were shallower (three and four meters respectively), due to difficulty in penetrating deeper levels. For the samples, elevations were obtained using a level and theodolite during field surveys. The design of the augers used meant that each $0.5 \mathrm{~m}$ in depth resulted in a single sample being recovered. While this method is generally not enough accurate to develop a fine-scale reconstruction of deposition, it is possible to recognize the main depositional environments. Since the Dalmaj and Nahrawan areas are part of the Mesopotamian floodplain, riverine are the main type of deposits. Based on the sediments' grain sizes, colours, microfossils, and organic matter, this environment can be divided into channel, floodplain, crevasse splay, and marsh sub-environments (Jotheri et al. 2017). The channel deposits consist of coarse grain sediments that are mainly grey-fine sand; floodplain deposits consist of massive blocks of clay and sandy to silty clay; crevasse splay deposits are characterized by very light grey fine sand, silty sand to fine silt; marsh deposits are of clay to silty clay. Deposits were dated using AMS, where possible, using shells, charcoal, or gyttja. Problems with dating accuracy can occur in all of these materials, although shells and gyttja can be particularly problematic, where introduced carbon may not give a date of deposition (Lougheed et al. 2017). While acknowledging such issues, we have minimized this by presenting results where we feel there is some relative accuracy given by the fact that dates follow a chronological order (e.g., bottom layers are older) or there is good context, such as ceramics being found between dates obtained that suggest a general accuracy of dates (e.g., see Nippur below).

The samples from the Shatt en-Nil, the large channel running north to south that divides Nippur into massive western and eastern tells, were recovered from excavations during Seasons 13-14 (19751976) of the Nippur Expedition, although the results presented here are new. The channel is believed to be the remains of an ancient Euphrates channel or canal; it is famously known from a Kassite map of Nippur and very likely existed for most of the history of the site (Kramer 1956: 271-275; Gibson 1985). In order to examine historic environmental conditions in the vicinity of this feature, a trench was excavated with heavy mechanical equipment normally used for construction and maintenance of large irrigation canals and drainage structures. The excavation, "Trench 2," was approximately 200 by 2 meters, with a maximum depth of 5.5 meters (Fig. 3). In some locations at the bottom of the trench, hand-excavated pits were used to allow sampling at a greater depth.

\section{Petrography}

Analyses of sediments included grain size and structural analysis, including composition and morphology. Samples from Dalmaj and Nahrawan were sent to the Department of Earth and Environmental Sciences, University of Milano-Bicocca in Italy for bulk petrography and heavy mineral analysis. The intent was to determine the likely origin of the sampled area's palaeochannels, specifically if the samples derived from one of the major rivers such as the Tigris or Euphrates, using mineralogy from given regions. Samples A1-5, A2-3, and A4-4 were analysed from the Dalmaj area; the Nahrawan samples A9-3 and A10-4 were also used. Mineral compositions of the samples were compared with samples from the Tigris, Euphrates and Diyala rivers. Quantitative petrographic analysis of sand within samples was carried out by pointcounting in thin section (Gazzi-Dickinson method; Ingersoll et al. 1984). Sands were classified according to the relative proportions of quartz, feldspars, and lithic fragments (Garzanti 2016). Heavy mineral analyses were carried out using a $32-500 \mu \mathrm{m}$ size window obtained by dry sieving. 


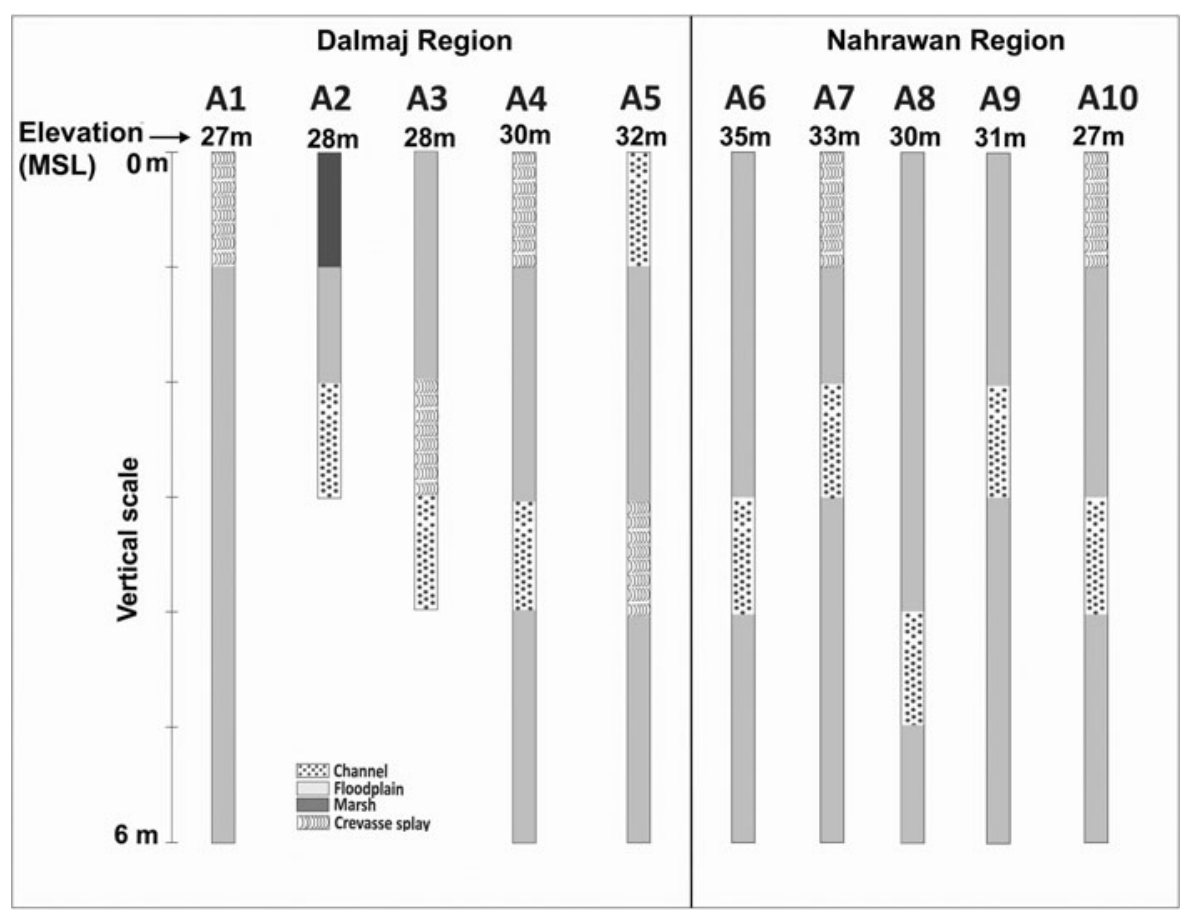

Fig. 2 Boreholes from the Dalmaj (A1-5) and Nahrawan (A6-10) regions. Elevation (mean sea level; MSL) is provided for the boreholes

Detrital grains denser than $2.90 \mathrm{~g} / \mathrm{cm}^{3}$ were separated by centrifuging in sodium polytungstate and recovered by partial freezing with liquid nitrogen. On grain mounts, 250 transparent heavy mineral grains were point-counted at suitable regular spacing to obtain real volume percentages using Galehouse's (1971) method. Compositional data of sediments carried by the Euphrates, Tigris, and Diyala Rivers used for comparison are from Garzanti et al. (2016). Relative sediment contributions from these rivers were assessed by forward mixing models based on integrated bulk petrography and heavy mineral data (Garzanti et al. 2012).

\section{Phytoliths}

Another analysis conducted involved identifying phytoliths from sediments. Phytoliths, which are silicified plant cells that are deposited into sediment when plants decay, were extracted from samples using a protocol by Rosen (1992, 2005; Fig. 4). Each sediment sample analysed, which contained phytoliths, was about $2.5 \mathrm{~g}$. Hydrochloric acid (10\%) was added to eliminate the carbonates. Clays were then separated out, using the manual settling method, and the samples were dried and then furnaced at 500 degrees Celsius for two hours to burn off any organic material. The phytoliths and other silica microfossils were separated from the remaining sediment using sodium polytungstate. The extracted microfossils were then placed on slides and mounted with Merck New Entellan. Slides were examined under an Alpha shot transmitted light microscope. Phytoliths were identified and counted, with an ideal minimum of 400 for single cells and 100 for multicells.

Count size is important as a too-low count can introduce biases into the results, mainly via misidentification and under-representation of taxa that do not produce as many phytoliths (Strömberg 2009). Monocotyledons (i.e., grasses, reeds, sedges, palms, etc.) generally produce the largest numbers of phytoliths, both single- and multicells; many trees and shrubs (dicotyledons) also produce them although generally in smaller numbers (Piperno 2006). Differential preservation may also introduce biases. Sediment geochemistry, sediment deposition, sediment transport, soil formation and phytolith types all can impact preservation, with some more robust morphotypes, 


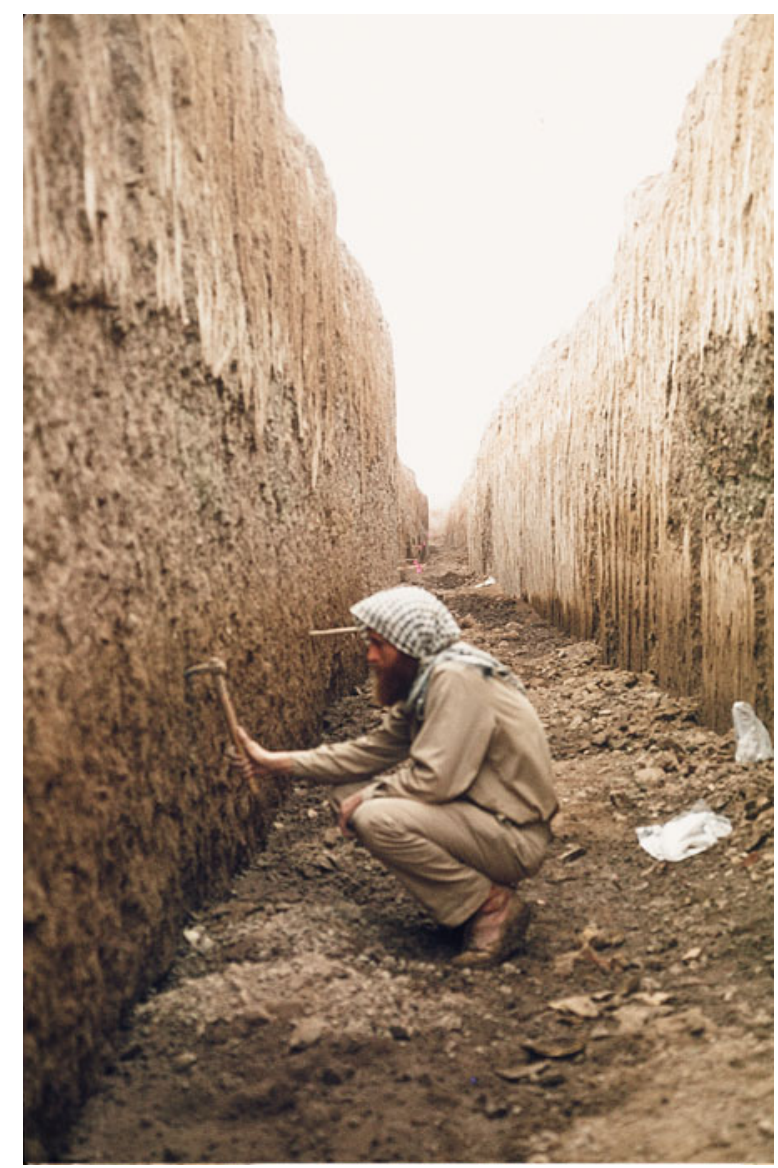

Fig. 3 Trench 2, excavated across the Shatt en-Nil at Nippur. Sediment characteristics were generally homogeneous

such as bulliforms, being over-represented. This is somewhat mitigated with higher minimum counts where possible.

In addition to the boreholes from the Dalmaj and Nahrawan regions, previously excavated sediments from a machine cut near the Uruk region (Jotheri et al. 2017; M38) are used to provide phytoliths newly studied here. Sediment samples from Nippur's Shatt en-Nil (Trench 2) are also analysed for their phytoliths.

\section{Speleothems}

An approximately three meter long stalagmite sample was recovered from Shalaii cave from the Kurdistan region of Iraq (SHC-3) and was analysed for proxy palaeoclimate data. This provides proxy paleoclimate data relevant for informing on rainfall that would have affected southern Mesopotamia's river systems. Analysis of the speleothems included measuring thickness of annual growth bands in the stalagmites, measured in high-resolution (4,800 dpi) with the software ImageJ. Stable carbon $\left(\delta^{13} \mathrm{C}\right)$ and oxygen $\left(\delta^{18} \mathrm{O}\right)$ isotope analyses were also applied; samples were micromilled at $1 \mathrm{~cm}$ increments. The powdered samples were then measured using a Finnigan Delta V Advantage mass spectrometer equipped with an automated carbonate preparation system (Gas Bench II) from the Chemical Analytical Facilities (CAF) at the University of Reading. The reported values are provided relative to the international Vienna Peedee Belemnite (VPDB) standard. The methodology is the same as Flohr et al. 2017 and Marsh et al. 2018.

Stable isotopes of oxygen and carbon $\left(\delta^{18} \mathrm{O}\right.$ and $\left.\delta^{13} \mathrm{C}\right)$ are among the most widely used proxies for palaeoclimate research and provide a 'common currency' that can be used to link records from across 

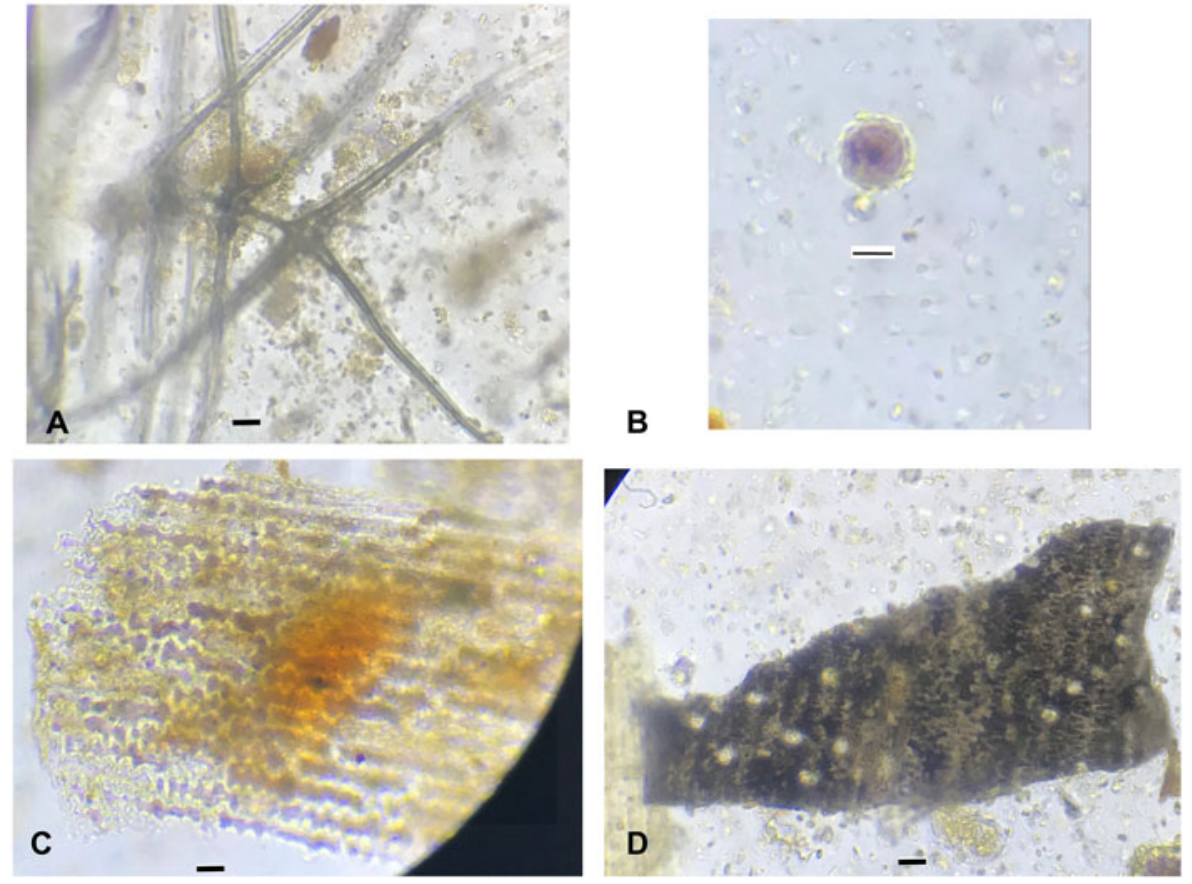

Fig. 4 Phytoliths; A) trichome from an oak (Quercus sp.), B) date palm (Phoenix dactylifera), C) multicell grass husk, and D) burnt cereal (probably barley)

a region (Roberts et al. 2018). Oxygen isotope variation in calcite can be caused by changes in a number of variables, including moisture source, temperature, rainfall amount and effectivemoisture (P:E; Lachniet 2009). $\delta^{18} \mathrm{O}$ calcite values from Near Eastern speleothems are thought to reflect changes in the amount of rainfall and effective moisture (P-E; Bar-Matthews et al. 1997; Cheng et al. 2015; Flohr et al. 2017), although the source effect is a significant control on longterm time-scales. This is the case with Shalaii cave, where previous monitoring has established calcite growth, moisture level change, temperature and $\delta^{18} \mathrm{O}$ of cave drip water. These values were used to calculate the theoretical calcite value of $\delta^{18} \mathrm{O}$, which indicated the speleothems were deposited very close to isotopic equilibrium (Marsh et al. 2018). Speleothems formed at or close to isotopic equilibrium are primarily influenced by variations in drip-water $\delta^{18} \mathrm{O}$, which, in turn, iare primarily influenced by rainfall amount (McDermott et al. 2006).

\section{Results}

Below, we summarize the new results obtained by our work and present a discussion that brings in outside data.

\section{The Dalmaj Samples}

The sediments are mainly clay, with varying components of silt and sands. The sediments indicate generally low velocity flow, which is typical for a low-lying region. Figure 2 shows switching between channel and floodplain deposits, with A1 and A3-5 showing evidence of crevasse splays and A2 showing evidence of marsh deposits. Three samples were collected for mineralogical analysis from the Dalmaj area (A1-5, A2-3, A4-4). The samples were found to be quartzofeldspathic lithic sands (i.e., comprised of silica and feldspars), characterised by common plagioclase (feldspar), carbonate rock fragments, and intermediate to mafic volcanic grains. Relative to the Nahrawan samples (see below), they have higher quartz (monocrystalline/ polycrystalline quartz ratio), K-feldspar, volcanic, plutonic rock fragments, and medium-rank to high-rank metasedimentary grains. Cellular serpentinite and serpentine-schist grains are particularly distinctive. Micas are common, with biotite dominating over muscovite. Heavy 
mineral assemblages are moderately rich, with amphibole prevailing over epidote and clinopyroxene, and minor garnet, $\mathrm{Cr}$-spinel, apatite, hypersthene, and enstatite. Dalmaj palaeochannel sands are richer in volcanic detritus than Tigris sand and richer in sedimentary detritus than Euphrates sand. Mica is more common, and quartz and heavy mineral concentrations are lower than in both Euphrates and Tigris bedload, which is accounted for by the fine grain size of the samples analysed (Garzanti et al. 2010). Forward compositional modelling indicates equal contribution of the Euphrates and Tigris rivers in the formation of the Dalmaj sediments. This suggests that the Dalmaj region was likely located close to or downstream of a confluence between the Tigris and Euphrates in earlier parts of the Holocene. As we could not obtain dates for those samples, we do not know when this would have occurred, but given the depths and dating we have from A3, we suggest a early to mid-Holocene date (i.e., pre-Ubaid up to the Uruk period). Throughout much of the Holocene, the two rivers were generally near each other in this part of the plain.

Figure 5A shows the absolute phytolith and microfossil counts per gramme. For all of the samples, it is quite low, likely due to soil processes. As can be seen from Figure 5B, monocotyledons (mainly grasses) outnumber dicotyledons (mainly trees and shrubs), which is to be expected given that monocotyledons produce more phytoliths overall. The proportions fluctuate in all of the samples, although no pattern is evident. Figure 5C shows the proportions of grasses (wild and cereals), wetland plants (reeds and sedges), date palms and dicotyledons, while excluding other monoctyledons. As can be seen, there are temporal fluctuations in the proportions, with increasing grasses in relatively more recent times (i.e., A1-1, A1-2; A2-1, A2-2). Figure 5D shows the numbers of other types of silica microfossils found in these cores. Other microfossils include nondiatom algae and sponges, all of which indicate aquatic conditions, indicating the Dalmaj has long been an alluvial area.

Dalmaj samples, A3-4 and A3-3, dated to approximately 7600-7550 cal. B.C. and 5750-5650 cal. B.C. respectively. Overall, we see that the plant communities changed, with changing proportions of dicotyledons, wetland plants and grasses, and a hint of fruit cultivation through the presence of date palm in some samples. The samples generally indicate a more temperate climate (as compared to the present) with $\mathrm{C} 3$ grasses dominating and few $\mathrm{C} 4$ grasses. There are also few reeds (mainly Arundo donax). From A3-4, dicotyledons found include Quercus sp., what appears to be oak (i.e., similar to Figure 4A), while date palm (Phoenix dactylifera; similar to Figure 4B) was also found. Date palm in southern Iraq is expected, although in the eighth millennium B.C. this is relatively early. What is particularly unexpected is the presence of oak this far south. These results also suggest likely more humid conditions in southern Iraq between the eighth and sixth millennia B.C. Oak disappears above A3-3, indicating that sometime after approximately $5750-5650$ cal. B.C. oak is no longer present.

\section{The Nahrawan Samples}

In general, the Nahrawan samples show a similar pattern of channel and floodplain deposits as the Dalmaj samples and have similar characteristics in grain size, colour and composition. More specifically, samples A9-2 and A9-4 were both clay, indicating a low velocity depositional environment, such as a backswamp floodplain, located away from the main channel. A9-3 consisted of silty fine sands, indicating a slight increase in velocity and more characteristic of overbank channel deposits. This indicates some movement in the river channel. Sample A10-4 consisted of sandy silts and fine sand, which are indicative of channel deposits. Samples from A9-3 and A10-4 were used for heavy mineral analysis. The Nahrawan palaeochannel sands are quartzofeldspatho-lithic like Dalmaj sands, but much richer in limestone and chert grains. Heavy mineral assemblages are similar but much poorer and contain kaersutite and oxy-hornblende but lack orthopyroxenes. Chert abundance indicates significant supply from the Diyala River, whereas low heavy mineral concentration and relative abundance of $\mathrm{Cr}$-spinel indicates recycling of forelandbasin sediments accreted to the Zagros foothills (Garzanti et al. 2016). Quartz, serpentinite, medium/high-rank metamorphic rock fragments, and mica are lower than in Tigris sand; forward compositional modelling indicates contribution from the Tigris and Diyala in about a 2:1 ratio. In other words, during the time these channels were active, between about 10,500-5200 cal. B.C., they 


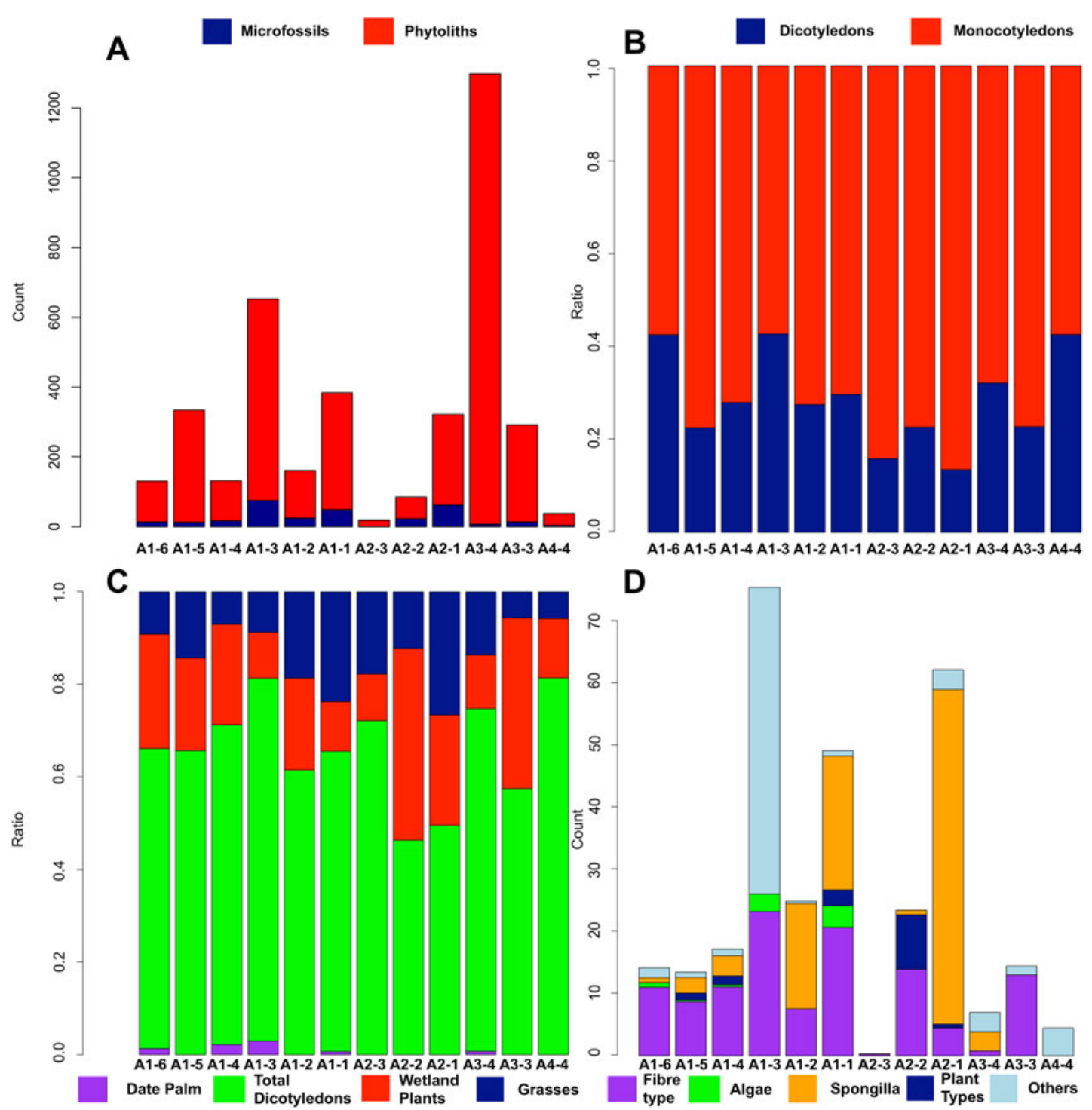

Fig. 5 Dalmaj: A) phytolith counts, B) proportion of monocotyledons to dicotyledons, C) types of plants, and D) other types of silica microfossils

were influenced by those two rivers, with a likelihood that the Nahrawan was a part of the ancient Tigris prior to it becoming a canal. This would substantiate claims by Hritz (2010) about the Nahrawan's origin being linked to an ancient branch of the Tigris and the canal's reuse of an older, relict channel.

Figure 6A shows the phytolith counts per gramme for the Nahrawan. Single cells dominate, with very few multicells represented (Fig. 6B). Figure 6C shows the ratios of monocotyledons (grasses, wetland plants, palms) and dicotyledons (mostly trees and shrubs); monocotyledons dominate, but dicotyledons are significant. There is some fluctuation through time as indicated by borehole A9. Figure 6D compares proportions of dicotyledons, grasses (cereals and wild), wetland plants and date palms. We were also able to obtain two dates from A9: about 10,500-10,175 cal. B.C. (A9-4) and 5300-5200 cal. B.C. (A9-2), which also indicates that about two meters of sediment was deposited in about 5000 years and two meters was deposited in the subsequent 7000 years, not accounting for erosion and compaction. The sediments reflect a changing river course, shifting from clay (distal backswamp) to fine sands (overbank deposits) and back to clay. In the first clay 


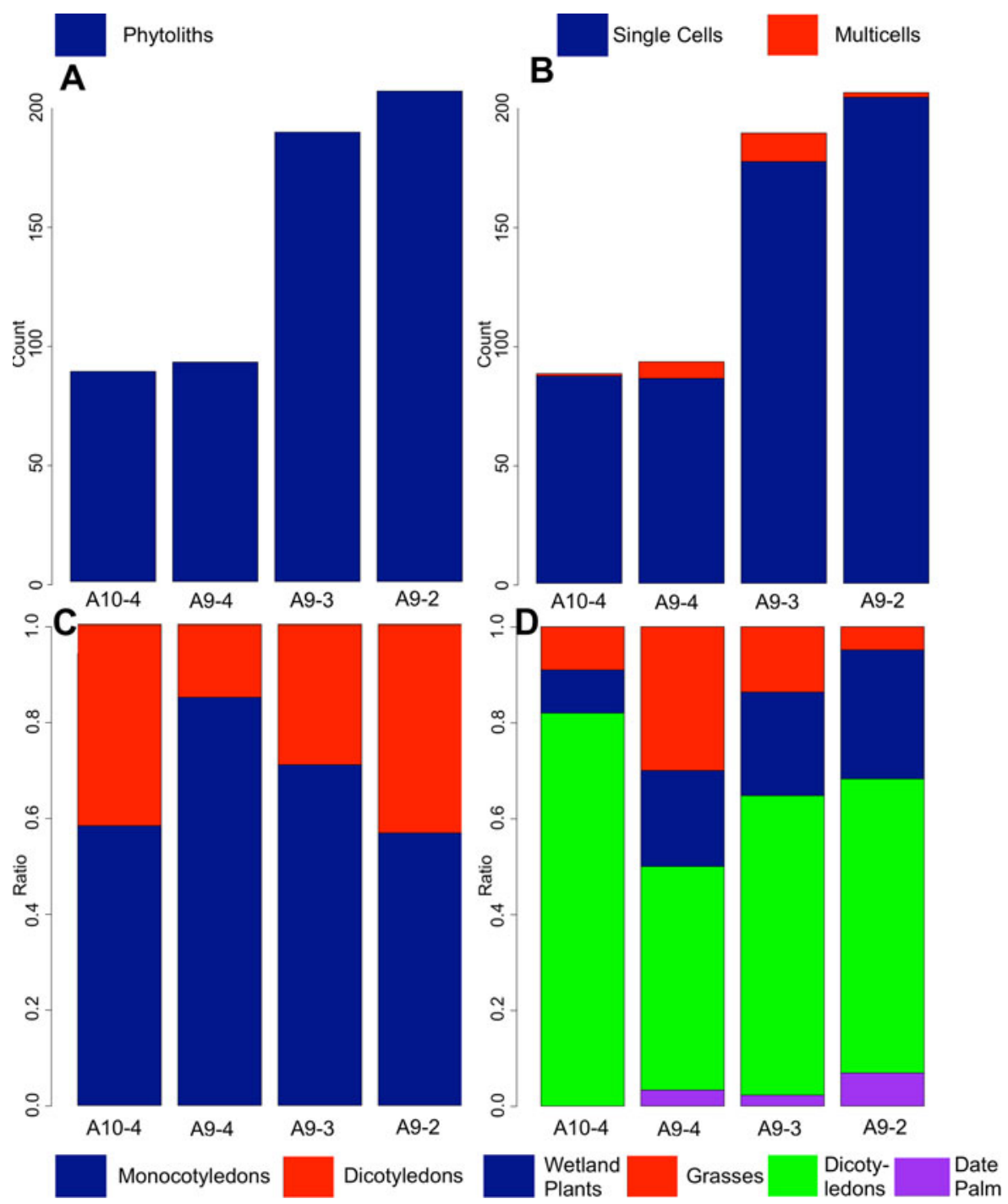

Fig. 6 Nahrawan: A) phytolith counts, B) proportion of single cell vs. multicell phytoliths, C) monocotyledons versus dicotyledons, and D) plant types

sample (A9-4), there are far more wetland plants, but in A9-2, the other clay sample, dicotyledons are much more dominant. The first sample dates to around 10,000 B.C., near the beginning of the Holocene, which was particularly wet and warm, so the results are not surprising.

In borehole A9, there is a trend of increasing numbers of dicotyledons and date palms; increases in date palms could reflect increased cultivation in the late sixth millennium B.C. or early Ubaid. In all of the samples, there is also a correspondence between dicotyledons and date palm (which is a monocotyledon). The presence of date palm (Phoenix dactylifera) in sample A9-4 is significant because it shows that the tree was present in Iraq at a very early period. In fact, as far as we are aware, this is the earliest Holocene date for the presence of date palm in Iraq, indicating that it was likely a native species.

Once again, $\mathrm{C} 3$ grasses dominate, with very few $\mathrm{C} 4$ grasses, indicating, as with the other samples, that a more temperate climate regime operated, as compared to the present. There were also other types of silica microfossils, including diatoms and sponge spicules, which indicate a wet environment, typical for an alluvial environment. 


\section{Uruk Region Borehole}

Borehole M38 comes from an area near Uruk and Larsa. The samples analysed date from just after about 7750-7600 cal. B.C. (M38-12.5) and to before about 4900-4860 cal. B.C. (M38-7). Additional samples from this borehole (not analysed here) were previously assessed for microfossils including diatoms (Jotheri et al. 2017). The total number of phytoliths and other silica microfossils in this borehole is the highest of all samples analysed for off-site materials. They also fluctuate in a corresponding manner (Fig. 7A), which could be a result of preservation conditions, due to, for instance, sedimentation rates and soil processes; the numbers for both are highest from 10 to 11.5 $\mathrm{m}$, which correspond to after about $7750 \mathrm{cal}$. B.C. and before $4900 \mathrm{cal}$. B.C.

Figure 7B shows the proportions between monocotyledons and dicotyledons. The proportions fluctuate through time, starting near $60 / 40$ at $12 \mathrm{~m}$, shifting to $90 / 10$ at $11.5 \mathrm{~m}$ and $11 \mathrm{~m}, 80 / 20$ $(10.5 \mathrm{~m})$, then back to $90 / 10$ and finally to $50 / 50$ at $9 \mathrm{~m}$. The proportions also vary for single cells versus multicells, with the highest numbers of multicells found at 12 and $9 \mathrm{~m}$ depth. Figure $7 \mathrm{C}$ shows the varying proportions of grasses (cereals/wild grasses), wetland plants (sedges and reeds), dicotyledons and date palms. The results here are interesting in that they again reflect a changing environment. For example, at $12 \mathrm{~m}$, the proportion of dicotyledons increases. This reflects a typical riparian environment, consisting of trees, shrubs, grasses and wetland plants. At 11 and $11.5 \mathrm{~m}$, the number of dicotyledons decreases, while the numbers of grasses and wetland plants increase, reflecting a more marshy/wetlands type environment. At $10.5 \mathrm{~m}$, dicotyledons increase again, indicating an increase in riparian type environment, one that is positioned more closely to the channel. This could be overbank or a crevasse splay deposit. In the $10 \mathrm{~m}$ sample, once again, oak is present, but disappears from the later samples. Interestingly, barley is also evident, showing grain cultivation was happening nearby and was contemporary with the presence of oak. At 9.5 to $9 \mathrm{~m}$, we again have a marshy environment (channel likely moving away), as reflected by an increase in wetland plants and grasses, and finally at $9 \mathrm{~m}$, we have an increase of dicotyledons. The sediment here is a reddish clay, interpreted as floodplain deposits. These would be distal deposits and likely were exposed to oxygen (i.e., drier conditions) for the majority of the time due to their colour. The lack of water could also explain the reduction in wetland plants. Date palm is evident in most samples. They appear early on (just after 7750 cal. B.C.) and indicate firstly a fluctuating climate, followed by increasing seasonality towards the mid-Holocene. The numbers of sponge spicules are very high, especially at $11.5,11$ and $10 \mathrm{~m}$, with high numbers as well at 10.5 $\mathrm{m}$. The sponges are most prevalent in the marshy sediments, indicating standing or flowing freshwater; the presence of diatoms also supports this. In fact, in Jotheri et al. (2017), the diatoms from the $12.5 \mathrm{~m}$ level indicate the area was a possible swamp. The previous results published from M38-12.5 (Jotheri et al. 2017) and the phytoliths analysed here indicate that the area of M38 remained a freshwater environment between approximately $7750 \mathrm{cal}$. B.C. and $4900 \mathrm{cal}$. B.C. This supports conclusions that the region was conducive for settlement as early as the early eighth millennium B.C., with favourable freshwater conditions persisting afterwards.

\section{Nippur Samples}

Trench 2 showed limited stratification, with relatively homogeneous deposits of mostly buff-coloured clay and silt (Fig. 3). In several locations, there were concentrations of small shell fragments that were originally attributed to desiccation of marshes and deposits of highly wind-eroded pottery fragments, probably washed from the mound of Nippur. Identifiable cultural material in the trench included fragments of Kassite goblets in several locations, mostly concentrating at or around the levels of samples 302 and 303. The earliest sample is 300 and is at $5.5 \mathrm{~m}$ depth, and sample 311 was the last sample, near the surface; other samples come from $0.5 \mathrm{~m}$ intervals above 300 . Sample 301, for instance, is at $5.0 \mathrm{~m}$ depth. Dates for samples are in Table 1. Interestingly, no abandonment of Nippur is evident in the sediments, but this could mean such evidence may have been eroded or even dug out. The dated levels suggest that the Shatt-en Nil existed for much of Nippur's history.

While the sediments appeared largely undifferentiated, clear differences in plant remains were evident from phytolith analysis. The numbers of phytoliths per gramme far exceeded those from the other samples and are dominated (at around 80\%) by monocotyledons (mainly grasses; 

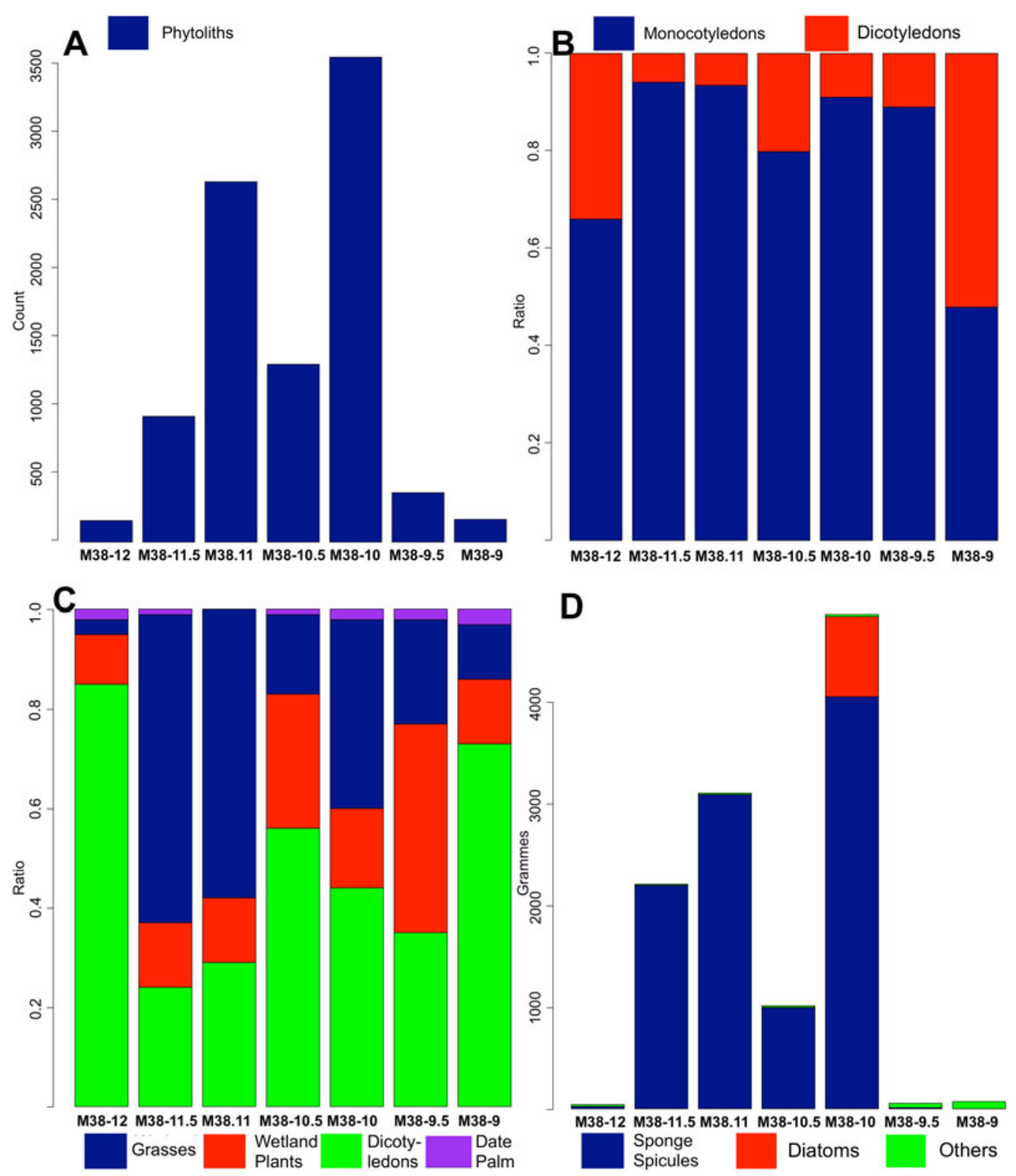

Fig. 7 M38 : A) phytolith counts, B) proportion of monocotyledons to dicotyledons, C) types of plants, and D) other evidence for freshwater microfossils

Fig. 8A-B). Wetland plants remain fairly consistent throughout the samples, but grasses and date palms fluctuate much more and seem to be negatively correlated (when there are more grasses, there are fewer palms and vice versa). There are fewer dicotyledons present in these samples than the other areas investigated, which could indicate a decline in trees/shrubs in the region (Fig. 8C). The overall high presence of date palms in the samples suggests these were grown very near Nippur's main channel throughout much of its history.

The negative correlation between date palm and grasses, which includes cereals, could indicate landscape management, whereby the main focus in this area switched between date palm and cereal cultivation. The presence of date palm is certainly more obvious in samples dating from the $26^{\text {th }}$ century B.C. and onwards, where this represents extensive cultivation likely occurring near or within Nippur. Date cultivation seemed to intensify after the mid-third millennium B.C., as 
indicated by samples 302, 303, and especially 304 (Parthian). Based on the ceramics from the levels of 302 and 303, we can roughly assume that 302 and 303 date to the late second millennium B.C.

The presence of the date palm and Arundo donax, reeds, as well as other C3 plants indicates the continuing presence of water and likely use of the channel for almost the entire recorded history of Nippur. There were also a few samples with large multicells (consisting of $10+$ cells), which is an indicator of increased water availability according to Rosen and Weiner (1994). Additionally, Madella et al. (2009) showed that the ratio of fixed to sensitive forms of phytoliths can also be used to detect irrigation, while more recently Jenkins et al. (2016) showed similar results to Madella et al. Given that rainfall levels are generally low in this region at this point, we suggest the presence of multicells likely resulted from irrigation from the channel that leads to increasingly saturated soils. It should be noted that not all samples contained these larger multicells, so there is an indication of either changing agriculture management strategies (i.e., less reliance on irrigation). There is a sudden increase in large multicells from sample 305 to 306, sometime around the Sasanian period (Fig. 8D).

Analysis of the Nippur samples indicates an environment where the climate regime was more set, although variable over time. The continued presence of $\mathrm{C} 3$ grasses and Arundo donax indicate a more temperate climate; however, it is likely that these are present due to irrigation/agriculture and the general dampness of the immediate vicinity, rather than reflecting regional climatic trends. The area was also much more intensively managed. Fluctuations in grains and date palm phytoliths seem to reflect agricultural strategies, rather than the result of natural environmental change from major shifts in climate. Date palms and grains appear to show a clear negative relationship, suggesting that land management and choice of cultivation of one affected the other. The increase in multicells during roughly the Sasanian period, or samples 305-306, is likely evidence for the intensification of the use of irrigation, at a rate likely more intense than earlier periods. In other words, this likely reflects irrigation expansion in the vicinity with more intense water flow. Overall, the results from Nippur are important because they span a long period (around three millennia) and illustrate the shifting agricultural strategies used at least in one area in and around the site.

\section{Speleothem Climate Results}

Our results for SHC-3, dated from about 8500 B.C. to today, are preliminary and require more work for accuracy, but a general assessment is made here. The SHC-3 record would appear to be the longest and most complete paleoclimate record for all of Mesopotamia during the Holocene. Figure 9 shows results from Shalaii's speleothems as well as additional regional data; it is further discussed below. Like existing records, the $\delta^{18} \mathrm{O}$ variation values are thought to reflect changes in rainfall amount (Marsh et al. 2018) and, therefore, evidence of a wetter early-mid Holocene climate relative to today is evident, while the more recent sample shows drying conditions similar to today but with volatile climate conditions. $\delta^{18} \mathrm{O}$ trends show that after the end of the fourth millennium B.C., there could be a shift towards generally drier conditions. These conditions could have prevailed for much of the rest of the Holocene, although periods of enhanced rainfall exist during this time. By the mid-first millennium B.C., and particularly over the last two thousand years, dry conditions appear evident, but conditions were volatile as well, sometimes reflecting short, wetter periods. These results need to be analysed further to develop a more detailed understanding for different climate trends within key archaeological periods and palaeoclimate events (e.g., 4.2 kya event).

\section{Discussion and Conclusion}

\section{North Iraq Climate Discussion}

This section summarises evidence for general changes in regional hydrological conditions using existing palaeoclimate records and other investigated records from northern Iraq. The Near East is still relatively neglected in terms of palaeoclimate investigations. High resolution palaeoclimate records that cover the Holocene are rare, and there exist large spatiotemporal gaps between those that do exist (Finné et al. 2011); this leaves a lot of uncertainty in our knowledge of hydrological conditions during the Holocene. 


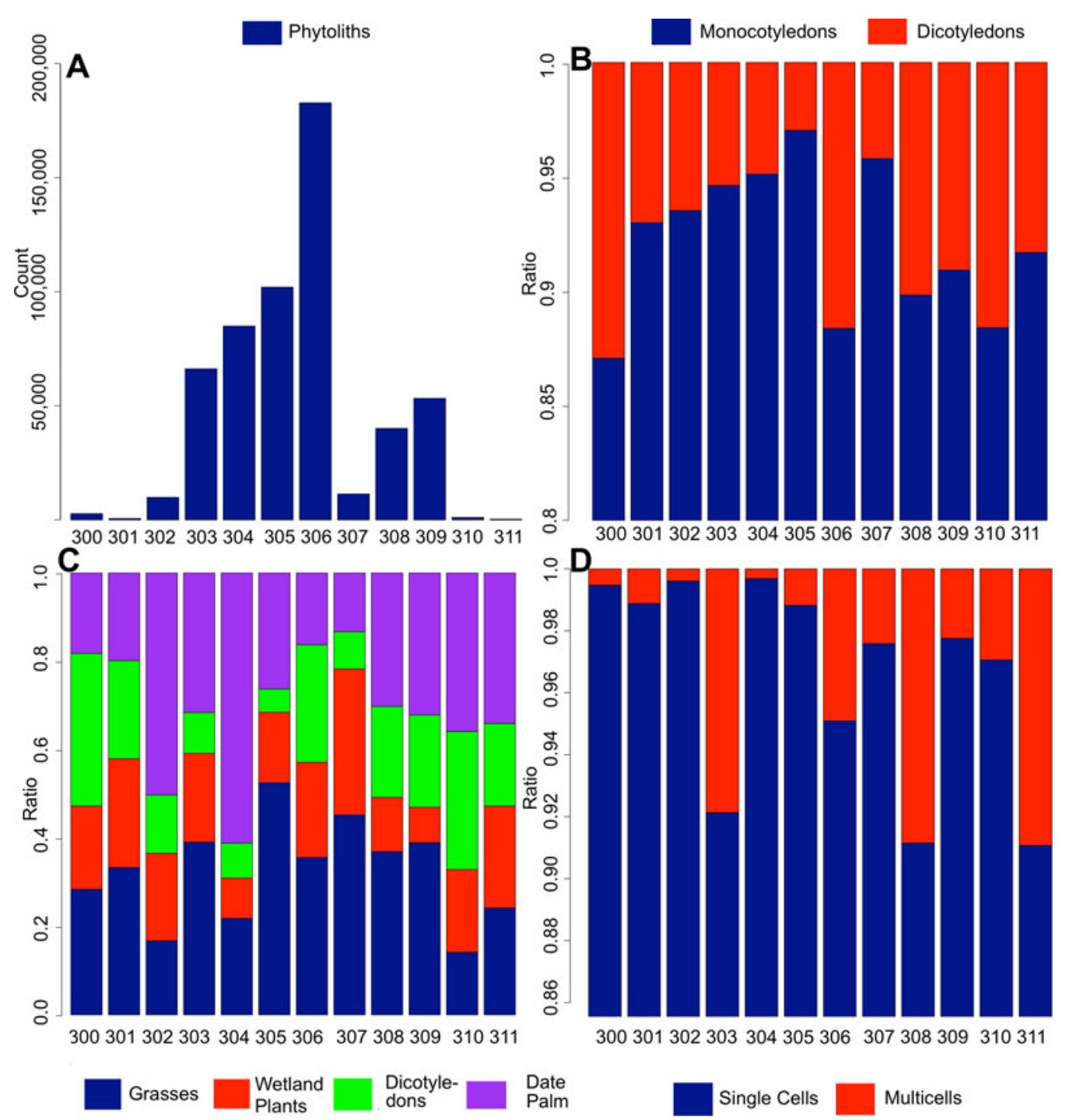

Fig. 8 Nippur: A) phytolith counts, B) proportion of monocotyledons to dicotyledons, C) types of plants, and D) single and multicells

The $\delta^{18} \mathrm{O}$ records from the region show significant shifts in climate during the Holocene and are generally coeval, which are also supported by other proxy evidence, although there were likely some fine-scale, regional variations. In fact, these variations necessitate local collection of palaeoclimate data. However, we can summarise a general picture of the region, which can then be compared to the records from southern Iraq. Following a short recovery after the Younger Dryas glacial reversal, the early Holocene $\sim 9,700-\sim 4,000$ B.C. was characterised by relatively depleted $\delta^{18} \mathrm{O}$ in speleothem and lake sediment records, an indication of wetter conditions; some of this depletion was caused by a change in source (Eastern Mediterranean) $\delta^{18} \mathrm{O}$, that is rain deriving from the Mediterranean region (Cheng et al. 2015). A decrease in dust flux evident from a lake record in northern Iran (Sharifi et al. 2015), where abundance of titanium (Ti) generally reflects wind blown dust, supports evidence of increased rainfall for the early Holocene, similar to our results. During the end of the mid-Holocene to late Holocene, by around $\sim 3,000$ B.C., there was a shift to more enriched $\delta^{18} \mathrm{O}$ values, similar to the present day. This is suggestive of drier conditions prevailing. Values remain similar for much of the rest of the Holocene, although there were periods of enhanced rainfall and prolonged drought, with a few records indicating that a wet phase prevailed 


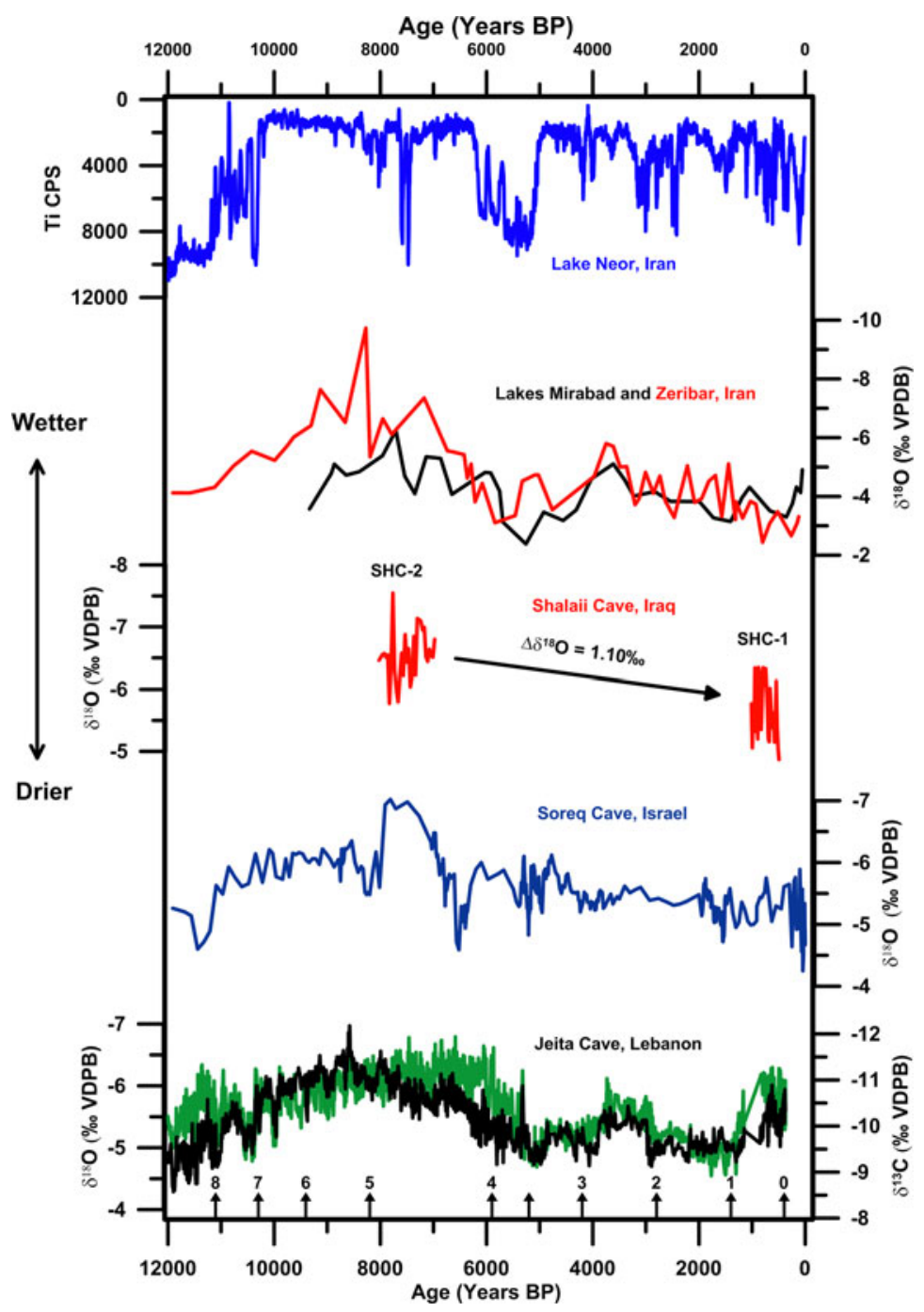

Fig. 9 Summary of palaeoclimate data from Shalaii cave reflecting trends from recovered speleothems and showing similarity to regional data (see Sharifi et al. 2015).

between $\sim 2,000$ and $\sim 1,000$ B.C. (Cheng et al. 2015; Roberts et al. 2011). $\delta^{18} \mathrm{O}$ values from lake sediments also support this trend (e.g., Roberts et al. 2011).

Previous analysis was conducted on speleothem samples from Shalaii cave, Kurdistan region of Iraq (Fig. 9). Two samples (SHC-1 and SHC-2; Marsh et al. 2018) cover different periods of the Holocene and allow for an insight into the change of $\delta^{18} \mathrm{O}$ and $\delta^{13} \mathrm{C}$ values between these periods in Northern Iraq. One sample, SHC-2, which was deposited between 8,025 B.P. (6,075 B.C.) \pm 38 and 6,977 B.P. $(5,027$ B.C. \pm 219 , has a mean oxygen isotope value of $-6.54 \%$ (VPDB). The younger sample, SHC-1, which grew between 1,012 B.P. (938) \pm 42 and 494 B.P. (1456) \pm 29 B.P., shows an average enrichment of $\sim 1.10 \%$ from SHC-02, correlating well with other speleothem records from the region, which show similar $\delta^{18} \mathrm{O}$ decreases of between $0.6 \%$ (Jeita) $-1.10 \%$ (Soreq) during the same period. While these two samples are relatively short in time, the third (SHC-3) more detailed sample shows some similar trends to the regional picture, although evidence for regional variations affecting northern Iraq are also evident (Table 1). 


\section{Southern Mesopotamia Environment}

Several noteworthy results relevant to the environmental history of southern Iraq are presented in this work. We see similar environmental patterns in the alluvial regions of the Nahrawan and Dalmaj. The general trend from phytolith and sedimentary results shows a more temperate (i.e., as compared to the present) climate regime was established early in the Holocene (c. 10,000 B.C.) in Iraq. The microfossils all indicate changes within alluvial and surrounding environments, changing from marsh/riverine, with mainly wetland plants and grasses, to floodplain and switching to river banks, with trees often composed of date palm. South of Baghdad and the region of Nahrawan are likely to already have been habitable by the eleventh millennium B.C. To the south around Uruk, the region was habitable for settlement at least by the early eighth millennium B.C. These results suggest early habitation prior to the earliest phases of the Ubaid was likely to be present south of Baghdad, even if material culture is lacking. A lack of evidence for the Persian Gulf in areas investigated and favourable settlement conditions from phytolith and diatom results suggest that by the early Holocene, and before the Ubaid, settlement was likely in many regions south of Baghdad and as far as the regions near Uruk. It is possible that earlier, pre-Ubaid cultures used less mud brick and, given the presence of more abundant wood and other building materials such as reeds, simply relied on these perishable resources more, thus making the detection of these cultures difficult using standard archaeological methods. The sediments suggest a very different Tigris-Euphrates system once existed. The Dalmaj region suggests the Tigris and Euphrates could have been joined near this area, sometime in the early to mid-Holocene, while the Nahrawan appears to have been a branch or part of the ancient Tigris prior to the development of the canal.

One key result is the evidence of date palms. From our results, date palms were already present by around cal. 10,500-10,175 B.C. In fact, results produced here show the earliest date for date palm from Holocene Iraq. Date palms require hot dry summers for the fruit to grow and ripen, but a perennial source of groundwater for their roots. It seems that quite early on (c. 10,000 years ago), the alluvial region of Iraq was conducive for date palms, and possibly the one rain system (winter and spring rains) may have been set in this region at the beginning of the Holocene, although other works suggest increased rainfall due to summer monsoon rains (e.g., Kennet and Kennet 2006). Regardless, the palaeoclimate does suggest wetter conditions in the periods prior to the fifth millennium B.C., which could suggest stronger rainfall feeding the rivers of southern Mesopotamia. Previously, the earliest archaeological evidence for the domesticated form of dates is from Eridu, from Ubaid levels (c. 7,000-6000 years ago; Zohary et al. 2013). According to archaeological evidence, fruit cultivation started during the Ubaid period in this region; it is likely, then, that the earliest phytoliths (i.e., pre sixth millennium B.C.) of date palms are from wild forms, whereas later date palms are more likely to be of the cultivated variety. The expansion of date palm in regions such as the Nahrawan and near Uruk, in the later layers, likely reflects at least some anthropogenic signature. However, we cannot exclude the possibility that date palms were cultivated even earlier than the Ubaid, as we suggest settlement in southern Mesopotamia likely occurred prior to the Ubaid. Regardless, date palm is clearly present throughout much of Iraq from the earliest phases of the Holocene, suggesting that dates grown in later periods likely derived from Iraq itself.

Another novel result is that oak was also present in southern Iraq, both in the Dalmaj and Uruk regions, between the eighth and sixth millennia B.C. No previous archaeological or historical data have discussed oak this far south in Iraq. Moreover, oak disappeared from later samples, which could occur due to increased aridity and/or increased human activity in southern Mesopotamia. From our results, we note that oak disappeared in records by the time of the earlier Ubaid and later Uruk expansions (Stein 2012; Algaze 2008). In other words, part of the motivation for expansion or even colonization/trade could have been the lack of quality wood materials in southern Iraq after the sixth millennium B.C.

At Nippur, the Shatt en-Nil was a long-lived channel that existed as an active canal/river channel throughout much of the city's history. The remains from Nippur suggest that during the late second millennium B.C. and Parthian period, date palms would have been substantially cultivated in parts of Nippur, with some date palm cultivation happening in the mid-third millennium B.C. Dates, in 
general, do not appear very frequently in textual sources from the third and second millennia B.C. Administrative texts from the third millennium B.C. indicate the use of date palm, via indirect citation in legal contexts such as transactions or agreements (Cocquerillat 1968; Landsberger 1967). Date palms were grown in irrigated orchards along with other fruit trees, such as figs, grapes, pomegranates, and apples in the late third millennium B.C. (Focke 2015; Greco 2015; Postgate 1987; Powell 1992). Given that most of the written records from the third and second millennia B.C. derive from public/state institutions, the lack of information on date cultivation is not entirely surprising. State and public institutions in the third and second millennia B.C. were heavily invested in cereal cultivation and to a much lesser degree in horticulture, as for example the cultivation of dates. There are some texts suggesting institutional involvement in date cultivation in the late third millennium B.C. (Focke 2015; Greco 2015), but it has been assumed that date cultivation was a more private/individual enterprise, as was true for example in pharaonic Egypt (Moreno Garcia, in press). However, until now, there were no empirical data that could provide a clue about the size of the non-institutional sector of early states' economies that was based on date cultivation. Hence, one result of the presented study is a more nuanced and holistic understanding of these early state economies. Additionally, trees were grown for timber in irrigated lands in the third millennium B.C. (Selz 2011). Textual sources suggest that dates were part of the regular diet, but the volume of grain-related texts has generally minimized the importance of dates. Our results suggest dates were relatively important for the Bronze Age economy, although in the mid-third millennium B.C. they were not as prevalent as in the second millennium B.C. (Kassite) levels, and their importance continued well into the first millennium A.D. Overall, there appears to be a negative relationship between date palm and grain cultivation in the area sampled.

The most detailed insight into the agricultural regime of the Nippur region is provided by the archive of the Murašu agricultural firm, which managed large amounts of arable land around Nippur in the fifth century B.C. on behalf of their owners. A major shift towards intensive horticulture of date palms at the expense of cereal cultivation took place during that period in other areas of the alluvial plain. From texts in the first millennium B.C., during the Achaemenid and Hellenistic periods, there is evidence of widespread date cultivation, in particular in more northern regions such as around Sippar, with even a cash crop economy revolving around the date palm (Jursa 2006). However, the Murašu archive deals primarily with cereal cultivation, with very little direct information on date cultivation (Jursa 2010: 407). References to the cultivation of dates are only found in debt notes, in which those to be paid by members of the Murašu agricultural firm were reckoned in large quantities of dates. Other references to date cultivation are rents collected in the form of quantities of dates for the leasing of garden plots (Jursa 2010: 410-411). Furthermore, Jursa (2010: 409, 413) suggests that date cultivation was not as prevalent in the Nippur region as elsewhere, consisting probably of medium to modest sized gardens tended to by individual families. The large quantities of dates listed in debt notes are thus to be understood as the obligation of a collective of tenants or farmers.

Although irrigation was present in Nippur in the earliest levels from the phytoliths analysed, it greatly expanded around the time of the Sasanian period, from the third century A.D. or later. This is supported by historical sources from the region that show expansion of irrigation during the Sasanian period (Campopiano 2017). Our results likely reflect the major irrigation works that began to be created by this period. Volatile climate could have been one problem faced in irrigation, as evident from climate data, where alternating periods of high rainfall and very dry years could have been frequent at least by the first millennium B.C., and into later periods. From a methodological view, phytolith analysis proved useful in differentiating the homogeneous remains from the Shatt en-Nil.

What the results most clearly demonstrate is the potential use of these multidisciplinary approaches, applied here in southern Mesopotamia. Furthermore, linkages between rainfall patterns in northern Iraq, via speleothem data, can be made to events in southern Iraq, including changes in the hydrologic regime and changes to the environment and plant communities (e.g., the disappearance of oak in southern Iraq). Future work should certainly focus on validating the 
observations presented here, as we recognize that remains from a limited number of samples do not mean wide-scale trends across southern Mesopotamia. Nevertheless, we are now better able to reconstruct plant communities and the local environments and how they were affected/modified by human activity and natural climate variations.

\section{Acknowledgements}

We are deeply grateful to the Neubauer Collegium for Culture and Society at the University of Chicago for funding the fieldwork, analysis and a 2018 conference that allowed collaborators to share results. The Neubauer also generously organized and hosted the conference. In addition, earlier funding from the Japanese Society for the Promotion of Science (JP26283012: C.E. Watanabe) helped fund our work near Uruk. The National Geographic Society also provided funding to conduct fieldwork and analysis. Funding from the British Institute for the Study of Iraq helped cover our work in Shalaii cave.

\section{References}

Adams, R. M. 1981. Heartland of Cities: Surveys of Ancient Settlement and Land Use on the Central Floodplain of the Euphrates. Chicago: University of Chicago Press.

1965. Land Behind Baghdad: A History of Settlement on the Diyala Plains. Chicago: University of Chicago Press.

Algaze, G. 2008. Ancient Mesopotamia at the Dawn of Civilization: The Evolution of An Urban Landscape. Chicago: University of Chicago Press.

1993. The Uruk World System: The Dynamics of Expansion of Early Mesopotamian Civilization. Chicago: University of Chicago Press.

al-Hamdani, A. 2014. The Shadow States: The Archaeology of Power in the Marshes of Southern Mesopotamia. PhD Dissertation, State University of New York Stony Brook.

Bar-Matthews, M., A. Ayalon, and A. Kaufman. 1997. "Late Quaternary Paleoclimate in the Eastern Mediterranean Region from Stable Isotope Analysis of Speleothems at Soreq Cave, Israel". Quaternary Research 47(2): 155-168.

Blaschke, T. 2018. Euphrat und Tigris im Alten Orient. Leipziger Altorientalische Studien 6. Wiesbaden: Harrassowitz Verlag.

Brandt, M. C. 1990. "Nippur: Building an Environmental Model". Journal of Near East Studies 49(1): 67-73.

Campopiano, M. 2017. "Cooperation and Private Enterprise in Water Management in Iraq: Continuity and Change between the Sasanian and Early Islamic Periods (Sixth to Tenth Centuries)". Environment and History 23(3): 385-407.

Cancik-Kirschbaum, E. and N. Ziegler, eds. 2009. Entre les Fleuves I. Untersuchungen zur Historischen Geographie Obermesopotamiens im 2. Jahrtausend v. Chr. Berliner Beiträge zum Vorderer Orient 20. Gladbeck: PeWe-Verlag.

Cancik-Kirschbaum, E. and C. Hess (with collaboration of K. Petrow). 2016. Toponyme der Mittelassyrischen Texte: Der Westen des Mittelassyrischen Reiches: Obermesopotamien im 2. Jt. v.Chr. Materialien zu Toponyme und Topographie I/2 [online]. Paris: Collège de France.

Cheng, H., A. Sinha, S. Verheyden, F. H. Nader, X. L. Li, P. Z. Zhang, L. Yin, L. Yi, Y. B. Peng, Z. G. Rao, Y. F. Ning and R. L. Edwards. 2015. "The climate variability in northern Levant over the past 20,000 years". Geophysical Research Letters 42(20): 8641-8650.

Civil, M. 1987. "Ur III Bureaucracy" in M. Gibson and R.D. Biggs, eds. The Organisation of Power: Aspects of Bureaucracy in the Ancient Near East. Studies in Ancient Oriental Civilization 46. Chicago: the University of Chicago Press, pp. 43-53.

Cocquerillat, D. 1968. "Palmeraies et cultures de l'Eanna d'Uruk (559-520)". Ausgrabungen der Deutschen Forschungsgemeinschaft in Uruk-Warka 8. Berlin: Gebr. Mann Verlag. pp. 72-74.

Cole, S. W. and H. Gasche. 1998. "Second- and first-millennium B.C. rivers in northern Babylonia" in H. Gasche and M. Tanret, eds. Changing watercourses in Babylonia. Towards a reconstruction of the ancient environment in lower Mesopotamia. Chicago: University of Chicago Press, pp. 1-158.

Fink, C. 2016. Fundorte und Karten. Materialien zu Toponyme und Topographie I/3 [online]. Paris: Collège de France. 
Finné, M., K. Holmgren, H. S. Sundqvist, E. Weiberg and M. Lindblom. 2011. "Climate in the Eastern Mediterranean, and Adjacent Regions, During the Past 6000 years-A Review”. Journal of Archaeological Science 38(12): 3153-3173.

Flohr, P., D. Fleitmann, E. Zorita, A. Sadekov, H. Cheng, M. Bosomworth, L. Edwards, W. Matthews and R. Matthews. 2017. "Late Holocene droughts in the Fertile Crescent recorded in a speleothem from northern Iraq: Late Holocene Droughts". Geophysical Research Letters 44(3): 1528-1536.

Focke, K. 2015. Der Garten in Neusumerischer Zeit. Alter Orient and Altes Testament 53. Münster: UgaritVerlag.

Galehouse, J. S. 1971. "Point counting" in R.E. Carver, ed. Procedures in sedimentary petrology. New York: Wiley, pp. 385-407.

Garzanti, E. 2016. "From Static to Dynamic Provenance Analysis: Sedimentary Petrology Upgraded". Sedimentary Geology 336: 3-13.

Garzanti, E., A. I. Al-Juboury, Y. Zoleikhaei, P. Vermeesch, J. Jotheri, D. B. Akkoca and G. Vezzoli. 2016. "The Euphrates-Tigris-Karun River System: Provenance, Recycling and Dispersal of Quartz-Poor Foreland-Basin Sediments in Arid Climate". Earth-Science Reviews 162: 107-128.

Garzanti, E., A. Resentini, G. Vezzoli, S. Andó, M. Malusà and M. Padoan. 2012. "Forward Compositional Modelling of Alpine Orogenic Sediments". Sedimentary Geology 280: 149-164.

Garzanti, E., S. Andò, C. France-Lanord, G. Vezzoli, P. Censi, V. Galy and Y. Najman. 2010. "Mineralogical and Chemical variability of Fluvial Sediments. Bedload sand (Ganga-Brahmaputra, Bangladesh)”. Earth and Planetary Science Letters 299(3-4): 368-381.

Gibson, M. 1985. "Nippur. Back to Tablet Hill: Sixteenth Season at Nippur, 1985" in J.H. Johnson, ed. The Oriental Institute 1984-85 Annual Report. Chicago: Orient Institute, pp. 20-30.

_ 1974. "Violation of Fallow and Engineered Disaster in Mesopotamian Civilization" in T.E. Downing and McG. Gibson, eds. Irrigation's Impact on Society. Tuscon: The University of Arizona Press, pp. 7-20.

1972. The City and Area of Kish. Field Research Projects. Miami, FL: Coconut Grove.

1978. "Nippur Regional Project: Umm Al-Hafriyat" in J.A. Brinkman, ed., The Oriental Institute 1977-78 Annual Report. Chicago: Oriental Institute, pp. 20-26.

1977. "The Nippur Expedition" in J.A. Brinkman, ed., The Oriental Institute 1976-77 Annual Report. Chicago: Oriental Institute, pp. 24-34.

1976. "The Nippur Expedition” in J.A. Brinkman, ed., The Oriental Institute 1976-77 Annual Report. Chicago: Oriental Institute, pp. 22-28.

Greco, A. 2015. Garden Administration in the Girsu Province During the Neo-Sumerian Period. Biblioteca del Próximo Orient Antiguo 12. Madrid: Consejo Superior de Investigaciones Científicas.

Helbaek, H. 1960. "The Palaeoethnobotany of the Near East and Europe” in R.J. Braidwood and B. Howe, eds. Prehistoric Investigation in Iraqi Kurdistan. Chicago: University of Chicago Press, pp. 100-118.

1959. "Domestication of Food Plants in the Old World." Science 130 (3372): 365-372.

Heyvaert, V. M. A. and C. Baeteman. 2008. "A Middle to Late Holocene avulsion history of the Euphrates River: A Case Study from Tell ed-Dēr, Iraq, Lower Mesopotamia”. Quaternary Science Reviews 27 (25-26): 2401-2410.

Hritz, C., J. Pournelle and J. Smith. 2013. "Revisiting the Sealands: Report of Preliminary Ground Reconnaissance in the Hammar District, Dhi Qar and Basra Governorates, Iraq". Iraq 74: 37-49.

Hritz, C., J. Pournelle, J. Smith, B. Albadran, B. M. Issa, and A. al-Handal. 2012. "Mid-Holocene Dates for Organic-Rich Sediment, Palustrine Shell, and Charcoal from Southern Iraq". Radiocarbon 54(01): 65-79.

Hritz, C. 2010. "Tracing settlement patterns and channel systems in southern Mesopotamia using remote sensing". Journal of Field Archaeology 35(2): 184-203.

2005. Landscape and Settlement in Southern Mesopotamia: A Geoarchaeological Analysis. PhD Dissertation, University of Chicago.

Ingersoll, R. V., T. F. Bullard, R. L. Ford, J. P. Grimm, J. D. Pickle and S. W. Sares. 1984. "The effect of grain size on detrital modes: A test of the Gazzi-Dickinson point-counting method". Journal of Sedimentary Petrology 54: 103-116.

Jacobsen, T. 1960. "The waters of Ur”. Iraq 22: 174-185.

Jacobsen, T. and R. M. Adams. 1958. "Salt and Silt in Ancient Mesopotamian Agriculture: Progressive Changes in Soil Salinity and Sedimentation Contributed to the Breakup of Past Civilizations". Science 128 (3334): 1251-1258.

Jacobsen, T. 1982. Salinity and Irrigation Agriculture in Antiquity, Diyala Basin Archaeological Projects: Report on Essential Results, 1957-58. Bibliotheca Mesopotamica, v. 14. Malibu: Undena Publications.

Jenkins, E., K. Jamjoum, S. Nuimat, R. Stafford, S. Nortcliff, and S. Mithen. 2016. "Identifying Ancient Water Availability through Phytolith Analysis: An Experimental Approach". Journal of Archaeological Science 73 (September): 82-93. 
Jotheri, J., M. Altaweel, A. Tuji, R. Anma, B. Pennington, S. Rost and C. Watanabe. 2017. "Holocene Fluvial and Anthropogenic Processes in the Region of Uruk in Southern Mesopotamia". Quaternary International 483: 57-69.

Jotheri, J., M. B. Allen and T. J. Wilkinson. 2016. "Holocene Avulsions of the Euphrates River in the Najaf Area of Western Mesopotamia: Impacts on Human Settlement Patterns". Geoarchaeology 31(3): 175-193.

Jotheri, J. 2016. Holocene Avulsion History of the Euphrates and Tigris Rivers in the Mesoptamian Floodplain. $\mathrm{PhD}$ dissertation, Durham University.

Jursa, M. (with contributions by J. Hack1, B. Janković, K. Kleber, E. E. Payne, C. Waerzeggers and M. Weszeli). 2010. Aspects of the Economic History of Babylonia in the First Millennium BC: Economic Geography, Economic Mentalities, Agriculture, the Use of Money and the Problem of Economic Growth. Alter Orient and Altes Testament 377. Münster: Ugarit-Verlag.

Jursa, M. 2006. "Agricultural management, tax farming and banking: Aspects of entrepreneurial activity in Babylonia in the Late Achaemenid and Hellenistic periods" in P. Briant and F. Joannès, eds. La transition entre l'Empire achéménide et les royaumes hellénistiques. Paris: De Boccard, pp. 137-222.

Kennett, D. J. and J. P. Kennett. 2006. "Early State Formation in Southern Mesopotamia: Sea Levels, Shorelines, and Climate Change". Journal of Island \& Coastal Archaeology 1(1): 67-99.

Kramer, S. 1956. From the Tablets of Sumer. Indian Hills: Falcon's Wing Press.

Lachniet, M. S. 2009. "Climatic and Environmental Controls on Speleothem Oxygen-Isotope Values". Quaternary Science Reviews 28(5-6): 412-432.

Landsberger, B. 1967. The Date Palm and Its By-Products According to Cuneiform Sources. Archiv für Orientforschung. Beiheft 17. Graz: Selbstverlag E.Weidner.

Lougheed, B. C., S. P. Obrochta, C. Lenz, A. Mellström, B. Metcalfe, R. Muscheler, M. Reinholdsson, I. Snowball and L. Zillén. 2017. "Bulk Sediment ${ }^{14} \mathrm{C}$ Dating in an Estuarine Environment: How Accurate Can It Be?: Estuarine Bulk Sediment ${ }^{14}$ C Dating." Paleoceanography 32 (2): 123-31.

Madella, M., M. K. Jones, P. Echlin, A. Powers-Jones and M. Moore. 2009. "Plant Water Availability and Analytical Microscopy of Phytoliths: Implications for Ancient Irrigation in Arid Zones". Quaternary International 193 (1-2): 32-40.

Maekawa, K. 1974. "Agricultural Production in Ancient Sumer: Chiefly from Lagash Materials". Zinbun 13: $1-60$.

Marsh, A., D. Fleitmann, D. A. M. al-Manmi, M. Altaweel, D. Wengrow and R. Carter. 2018. "Mid- to lateHolocene archaeology, environment and climate in the northeast Kurdistan region of Iraq". The Holocene. https://doi.org/10.1177/0959683617752843.

McDermott, F., H. Schwarcz and P.J. Rowe. 2006. "Isotopes in speleothems". in M. J. Leng, ed. Isotopes in Palaeoenvironmental Research. Vol. 10. Dordrecht: Springer, pp. 185-226.

Moreno García, J.-C. (in press). "Wells, Small-Scale Private Irrigation and Agricultural Strategies in the 3rd and 2nd Millennium BC Egypt" in S. Rost, ed. Irrigation in Early States: New Directions. Oriental Institute Seminars 13. Chicago: Oriental Institute of the University of Chicago.

Morozova, G. S. 2005. "A Review of Holocene Avulsions of the Tigris and Euphrates Rivers and Possible Effects on the Evolution of Civilizations in Lower Mesopotamia". Geoarchaeology 20(4): 401-423.

Paepe, R. 1971. "Geological approach of the Tell ed-Dēr area, Mesopotamian plain, Iraq". Tell ed-Dēr I. Leuven: Peeters, pp. 19-27.

Paepe, R. and C. Baeteman. 1978. "Fluvial system between Tell ed-Dēr and Tell Abu Habbah". Tell Ed-Dēr II. Leuven: Peeters, pp. 37-56.

Piperno, D. R. 2006. Phytoliths: A Comprehensive Guide for Archaeologists and Paleoecologists. Lanham, MD: AltaMira Press.

Postgate, J. N. 1987. "Notes on Fruits in the Cuneiform Sources". Bulletin on Sumerian Agriculture 3: 115-144.

Pournelle, J. 2003. Marshland of Cities: Deltaic Landscapes and the Evolution of Early Mesopotamian Civilization. PhD Dissertation, University of California San Diego.

Powell, M. A. 1992. "Timber Production in Presargonic Lagaš”. Bulletin on Sumerian Agriculture 4: 99-122.

1985. "Salt, Seed and Yields in Sumerian Agriculture: A Critique of the Theory of Progressive Salinization". Zeitschrift für Assyriologie 75: 7-38.

Reculeau, H. 2015. "Middle Assyrian Agrarian Management in the West in the Light of its Forerunners" in B. S. Düring, ed. Understanding Hegemonic Practices of the Early Assyrian Empire. Publications de l'Institut Historique-Archéologique Néerlandaise de Stamboul 125. Leiden: Nederlands Instituut voor het Nabije Oosten, pp. 199-219.

2011. Climate, Environment and Agriculture in Assyria in the 2nd half of the $2^{\text {nd }}$ Millennium BCE. Wiesbaden: Harrassowitz.

2008. "Late Bronze Age Rural Landscapes of the Euphrates According to the Emar Texts" in L. d'Alfonso, Y. Cohen and D. Sürenhagen. eds. The City of Emar Among the Late Bronze Age Empires. Alter Orient und Altes Testament 349. Münster: Ugarit Verlag, pp. 129-140. 
Reimer, P. J, E. Bard, A. Bayliss, J. W. Beck, P. G. Blackwell, C. B. Ramsey, C. E. Buck. 2013. "IntCal13 and Marine13 Radiocarbon Age Calibration Curves 0-50,000 Years Cal BP.” Radiocarbon 55 (04): 1869-87.

Roberts, N., J. Woodbridge, A. Bevan, A. Palmisano, S. Shennan and 'E. Asouti. 2018. "Human responses and non-responses to climatic variations during the last glacial-interglacial transition in the eastern Mediterranean". Quaternary Science Reviews 184: 47-67.

Roberts, N., W. J. Eastwood, C. Kuzucuoğlu, G. Fiorentino and V. Caracuta. 2011. "Climatic, Vegetation and Cultural Change in the Eastern Mediterranean During the Mid-Holocene Environmental Transition". The Holocene 21(1): 147-162.

Rosen, A. M. 2005. "Phytolith Indicators of Plant and Landuse at Catalhoyuk" in I. Hodder, ed. Inhabiting Catalhoyuk: Reports from the 1995-99 Seasons. London and Cambridge: McDonald Institute for Archaeological Research and British Institute of Archaeology at Ankara, pp. 203-212.

Rosen, A. M. and S. Weiner. 1994. "Identifying Ancient Irrigation: A New Method Using Opaline Phytoliths from Emmer Wheat". Journal of Archaeological Science 21(1): 125-32.

Rosen, A. M. 1992. "Preliminary Identification of Silica Skeletons from Near Eastern Archaeological Sites: An Anatomical Approach" in G.R. Rapp, S.C. Mulholland, eds. Plenum Press: New York, pp. 129-147.

Rost, S. 2015. Watercourse Management and Political Centralization in Third-millennium B.C. Southern Mesopotamia: A Case study of the Umma Province of the Ur III period (2112-2004 B.C.). PhD Dissertation, State University of New York at Stony Brook, New York.

Sallaberger, W. 1999. "Ur III-Zeit" in W. Sallaberger and A. Westenholz, eds. Mesopotamien: Annäherungen 3, Akkade-Zeit und Ur III-Zeit. Orbis Biblicus et Orientalis 160/3. Freiburg Schw.; Göttingen: Universitätsverlag; Vandenhoeck \& Ruprecht, pp. 119-390.

Schrakamp, I. 2017. Das Bewässerungssystem des Präsargonischen Staates von Lagaš (ca. 2475-2310 v. Chr.). Habilitationsschrift, Freie Universität Berlin.

2015. "Geographical Horizons of the Presargonic and Sargonic Archives" in W. Sallaberger and I. Schrakamp, eds. Associated Regional Chronologies for the Ancient Near East and the Eastern Mediterranean 3. Turnhout: Brepols, pp. 197-270.

Selz, G. 2011. "Zur Holzwirtschaft im Altsumerischen Lagaš” in L. Vacín, ed. $U_{4} d u_{11}-g a-n i s a_{2} m u-n i-i b_{2}-d u_{11}$ : Ancient Near Eastern Studies in Memory of Blahoslav Hruška. Dresden: Islet Verlag, pp. 213-246.

Sharifi, A., A. Pourmand, E. A. Canuel, E. Ferer-Tyler, L. C. Peterson, B. Aichner and H. A. Lahijani. 2015. "Abrupt Climate Variability Since the Last Deglaciation Based on a High-Resolution, Multi-Proxy Peat Record from NW Iran: The Hand that Rocked the Cradle of Civilization?" Quaternary Science Reviews 123: 215-230.

Stein, G. J. 2012. "The Development of Indigenous Social Complexity in Late Chalcolithic Upper Mesopotamia in the 5th-4th millennia BC - An Initial Assessment. Origini 24(5): 115-142.

Strömberg, C. A. E. 2009. "Methodological Concerns for Analysis of Phytolith Assemblages: Does Count Size Matter?" Quanternary International 193: 124-140.

Vanderroost, N. 2012. Organisation Administrative du Bureau de l'Agriculture d'Umma à l'Époque de la Troisième Dynastie d'Ur. Ph.D., Faculté de Philosophie et Lettres, Université Libre de Bruxelles.

Verhoeven, K. 1998. "Geomorphological Research in the Mesopotamia Plain" in H. Gasche and M. Tanret, eds. Changing Watercourses in Babylonia: Towards a Reconstruction of the Ancient Environment in Lower Mesopotamia. Chicago: Oriental Institute University of Chicago, pp. 159-204.

Wilkinson, T. J. 2003. Archaeological Landscapes of the Near East. Tucson: University of Arizona Press.

Wilkinson, T.J. 1990. "Early Channels and Landscape Development around Abu Salabikh, a Preliminary Report". Iraq 52: 75-83.

Wright, H. 1980. "Problems of Absolute Chronology in Protohistoric Mesopotamia". Paléorient 6: 93-98.

Ziegler, N. and A.-I. Langlois (avec la collaboration de J. Patrier et A. Jacquet). 2016. Les Toponymes PaléoBabyloniens de la Haute-Mésopotamie. Materialien $\mathrm{zu}$ Toponyme und Topographie I/2 [online]. Paris: Collège de France.

Zohary, D., M. Hopf and E. Weiss. 2013. Domestication of Plants in the Old World: The Origin and Spread of Domesticated Plants in South-West Asia, Europe and the Mediterranean Basin. Oxford: Oxford University Press.

Mark Altaweel

Institute of Archaeology

University College London

Gordon Square

London WC1H 0PY UK

m.altaweel@ucl.ac.uk 
رؤى جديدة حول دور القوى البيئية الفاعلة في تشكيل وادي الرافدين: من قبل فترة العبيد الى العصر الإسلامي المبكر.

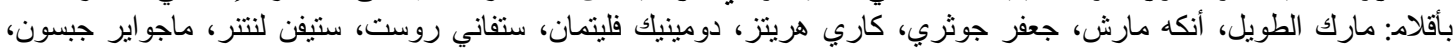

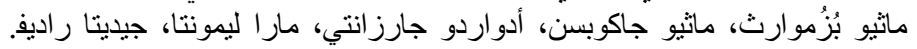

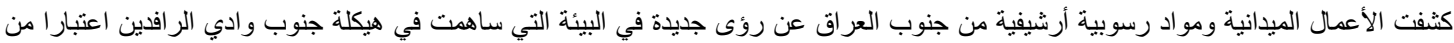

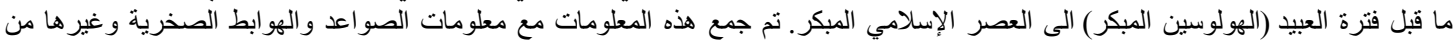

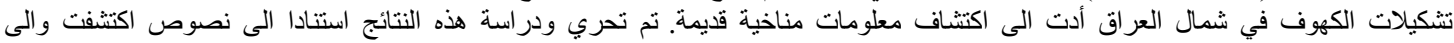

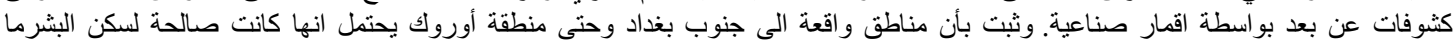

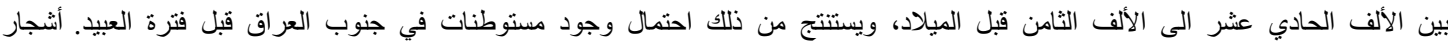

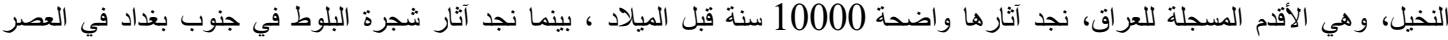

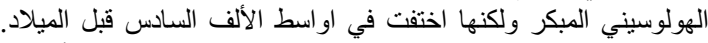

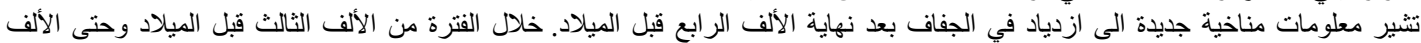

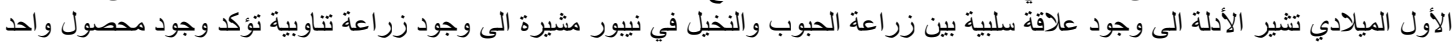

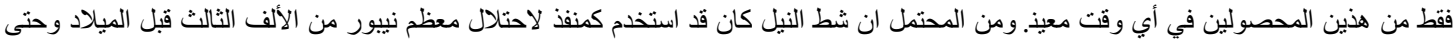

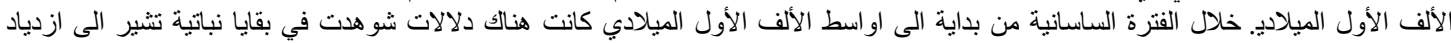

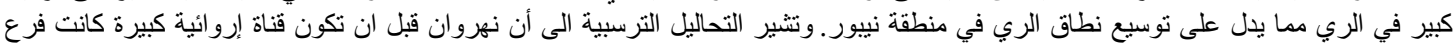

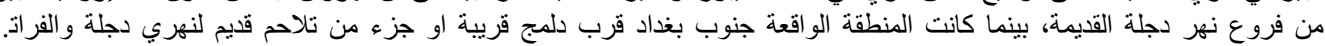

